\title{
MÉTODOS E ORDEM DAS CIÊNCIAS NO COMENTÁRIO SOBRE O DE ANIMA ATRIBUÍDO A PEDRO HISPANO
}

J. F. Meirinhos*

StNTESE - Nos três problemas preambulares e nas primeiras liçỏes do Commentarium in $\mathrm{De}$ anima atribuido a Pedro Hispano, o autor: 1) discute a possibilidade de uma ciência da alma; 2) compara a ciência da alma com as outras ciências naturais; 3) identifica 0 método da ciência da alma. Dai emerge uma fundamentação da "ciência da alma" como "ciéncia do homem" e um modelo de organização das ciências, tendencialmente coincidente com a organizaçâo do corpus aristotélico, mas com a reivindicação da superioridade da Clência da alma por razōes gnosiológicas
ABSTRACT - In the three praefatory problems and in the first lessons of the Commentarium in De anima, attributed to Peter of Spain, the author: 1) discusses the possibility of a science of the soul; 2) compares the science of the soul with the other natural sciences; 3) identifies the method of the science of the soul. From these reflections he lays the foundations of the "science of the soul" as the "science of men", and a classification of the sciences, which almost coincide with the organisation of the Aristotelian corpus, but with the vindication of the superiority of the Soul's Science by epistemological reasons.

Os séculos XII e XIII caracterizam-se por profundas alterações nos domínios do saber, fruto da dinâmica própria da vida intelectual do período imediatamente anterior, conjugada com a tradução e recepção de uma extensa biblioteca grega e árabe nos domínios da filosofia e das ciências, em simultâneo com a instauração de uma nova ordem pedagógica pelas universidades, de que resulta 0 alargamento e multiplicação dos campos disciplinares que muito rapidamente deixam de estar confinados ao modelo fundador das sete artes liberais. Estes factores transportam consigo ou suscitam de imediato uma profunda reflexâo sobre a classificação e organização do saber que integre o novo paradigma disciplinar e dê corpo às novas formas do discurso e da prática profissional de transmissão do saber e das ciências. A novidade da situação, mais do que questionar os esquemas tradicionais, instaura uma verdadeira crise de identidade no interior das ciências emergentes. De facto, não é apenas um desejo mais ou estético de ordem e organiza-

- Faculdade de Letras da Universidade do Porto, Portugal.

\begin{tabular}{|l|l|l|l|l|l|}
\hline VBRITAS & Porto Alegre & v. 43 & $\mathrm{n}^{2} 3$ & Setembro 1998 & p. 593-621 \\
\hline
\end{tabular}


ção que dá nova razão de ser à literatura de classificação das ciências, mas sim a resposta à tensão entre a defesa da nova literatura filosófica e a necessidade de evitar a desagregação ou a excessiva autonomia dos discursos das diferentes áreas do saber. É evidente uma estratégia defensiva para resistir aos ataques antiaristotélicos e às desconfianças dos teólogos e das autoridades eclesiásticas. Por isso, não é de todo improvável que os elogios da filosofia e as divisões das ciências que se encontram em grande parte dos comentários a obras de Aristóteles tenham origem na necessidade de justificar a sua leitura, contra as prevençōes que sobre elas haviam sido lançadas na universidade de Paris.

Esse espírito fervilha numa constelação de textos, extraordinariamente diversificados no conteúdo e no estilo, alguns escritos no século XII num contexto préuniversitário, de que são exemplo o Didascalicon, de studio legendi de Hugo de São Victor, herdeiro de séculos de cultura monástica ${ }^{1}$ e o De divisione philosophiae de Domingo Gundissalino, ${ }^{2}$ um verdadeiro manifesto dos novos ventos filosóficos, até às súmulas do De ortu scientiarum de Roberto Kilwardby ${ }^{3}$ de meados do século XIII e a Divisio scientiae de João de Dácia já do final desse século, ${ }^{4}$ obras que colhem os resultados de décadas de discussöes. Nesse longo período de quase um século e meio abundam as Divisões da filosofia, Divisões das ciências, Acessos aos filósofos e às Artes, Compêndios das matérias de exame, etc. ${ }^{5} \mathrm{~A}$ or-

1 Patrologia latina, 176, 770C-812B; ed. critica: Hugonis de Sacto Victore Didascalicon de studio legendi, ed. Ch. H. BUTTIMER (Studies in Medieval and Renaissance Latin, 10) The Catholic University of America, Washington (D.C.) 1939; ver: L. GIARD, "Hugues de Saint Victor: cartographe du savoir", in J. LONGËRB (ed.), L'Abbeye parisienne de Saint Victor au Moyen Äge (Bibliotheca Victorina, 1), Brepols, Turnhout 1991, p. 253-269.

2 DOMINICUS GUNDISSALINUS, De diuisione philosophiae, hrg. Ludwig BAUR (Beiträge GPM, 4/ 2 3) Aschendorf, Münster 1903. Ver: H. HUGONNARD-ROCHE, "La classification des sciences de Gundissalinus et l'influence d'Avicenne", in J. JOLIVET - R. RASHED (dir.), Études sur Avicenne, Les belles lettres, Paris 1984, p. 40-75. Para este estudo năo pude consultar a obra de Gundissalino, embora seja várias vezes citada no Comentário ao De anima atribuido a Pedro Hispano.

ROBERT KILWARDBY, O.P., De ortu scientiarum, ed. by A. G. JUDY (Auctores Britanici medii aevi, 4) The British Academy, London 1976.

4 Johannis Daci Diuisio scientiae, ed. A. OTTO, Johannis Daci Opera, t. I, p. 3-44 (Corpus philosophorum Danicorum modii aevi, 1) Hauniae 1955.

5 Muitos destes textos estāo inéditos embora uma parte importante já se encontre publicada por: G. DAHAN: "Une introduction a la philosophie au XII.e siècle. Le Tractatus quidem de philosophia et partibus eius" (in AHDLMA 41, 1982, 155-193) e "Une introduction ả l'étude de la philosophie: Ut ait Tullius (nas p. 3-58 in Cl. LAFLBUR - coll. de CARRIBR, eds., L'enseignement de la philosophie au XIIle siécle, cit. no final desta nota); - R.-A. GAUTHIER publicou a Philosophia de Albérico de Reims em "Notes sur Siger de Brabant, II. Siger en 1272-1275. Aubry de Reims et la scission des normands" (Revue des sciences philosophiques et théologiques 68, 1984, 3-49); - Cl. LAFLEUR publicou os Accessus philosophorum. VII artium liberalium de um Mestre anónimo, a Philosophica disciplina também de um anónimo, a Divisio scientiarum de Amulfo de Provença e o Compendium circa quadrivium, de outro anónimo, in Quatre introductions à la philosophie au XIIle siécle. Textes critiques et étude historique, Institut d'études médiévales, Librairie phil. J. Vrin, Montréal-Paris 1988, nas p. 387-394 deste volume pode ler-se também um repertório dos textos parisienses de introdução à filosofia. O famoso compêndio dos examinandos parisiense foi publicado por C. LAFLEUR, avec la coll. de J. CARRIER, Le "Guide de l'étudiant" d'un maitre anonyme de la Faculté des Arts de Paris au XIle siècle. Édition critique provisoire du ms. de Barcelona, Arxiu de la Corona d'Aragó, Ripoll 109, ff. 134ra-158va, Faculté de Philosophie, Université Laval, Québéc 1992. C. LAFLEUR è J. CARRIER (colab.) publicaram a introdução à filosofia Dicit Aristotiles, a Philosophia de Henrique o Bretão e mais dois textos breves na segunda parte de "La 
denação das ciências e 0 elogio da filosofia tomam-se uma verdadeira ocupação especulativa, que os mestres de artes abordam com tal frequência que se transformará em objecto de avaliação dos estudantes. ${ }^{6}$

A multiplicação destes textos ocorre no século XIII, quer em escritos autónomos quer em comentários ou em enciclopédias, pressentindo-se neles a fundamentação do conhecimento sobre determinado objecto e a busca de legitimação da corporação universitária e dos seus mestres, sobretudo no âmbito das faculdades de Artes cuja autoridade provém apenas do conteúdo e do prestígio do seu ensino, e não de uma instância não escolar como acontece em Teologia. A apologia da filosofia, que invariavelmente se encontra como introduçăo nesses textos, expressa uma permanente vindicação de autonomia e autotelia do saber transmitido nas faculdades de Artes, progressivamente estruturadoras da Filosofia como ciência, cujos limites permaneciam vagos apesar de corporizar o desejo de uma sabedoria filosófica que começava a formar-se no horizonte e contra a qual os teológos e as autoridades eclesiásticas reagiriam com dureza sobretudo em 1277, quando o seu espectro começava a pairar sobre Paris e Oxford. ${ }^{7}$ Note-se que é a

Philosophia d'Hervé le Breton (alias Henri le Breton) et le recueil d'introductions à la philosophie du ms. Oxford, Corpus Christi College 283" (in AHDLMA 61, 1994, p. 149-226 e vol. 62, 1995, 359442). Ainda C. LAFLEUR e J. CARRIER (colab.) publicaram diversos estudos e um mais extenso grupo do textos do mesmo tipo que inclui o Primo queritur utrum philosophia (também incluído como anexo III em Le "Guide de l'étudiant" d'un maître...), o prólogo Triplex est principium de Adenulfo de Anagni, a Philosophia de Olivero Bretão, o inicio de umas Questiones mathematice, todos na segunda parte do volume C. LAFLEUR e J. CARRIER (colab.) eds., L'enseignement de la philosophie au XIIle stècle. Autour du "Guide de létudiant" du ms. Ripoll 109. Actes du colloque international edités avec un complément d'études et de textes (Studia artistarum, 5) Brepols, Turnhout 1997.

6 Da vasta literatura recente sobre as divisōes e elogío da filosofia como problema de teoria da ciência e como matéria de exame ver, para além dos estudos cit. na nota anterior: J.A. WEISHBIPL, "The Nature, Scope and Classification of the Sciences", in D.C. Lindberg, Science in the Middle Ages, The Univ. of Chicago Press, Chicago-London 1978, p. 461-481; E.-H. WÉBER, "La classification des sciences à Paris vers 1250", in J. Jolivet - R. Rashed (dir.), Êtudes sur Aviconne, ed. cit., p. 77-101; C.S.F. BURNETT, "Innovations in the Classification of the Sciences in the Twelfth Century", in Knowledge and the Sciences in Medieval Philosophy, Helsinki 1990, vol. II p. 25-42; G. DAHAN, "Les classifications du savoir auX XIle et XIIle sićcles", L'enseignement philosophique 40 (1990) 5-27; S. NAGBL, "Scienze de rebus e discipline de vocibus nella tradizione delle classificazioni del sapere (secoli VII-XII)", Medioevo 10 (1994) 77-113; Cl. LAFLEUR, "Les "Guides de l'étudiant de la Faculté des arts de l'Université de Paris au XIIle siècle", in M.J.F.M. Hoenen - J.H.J. Schneider - G. Wieland (eds.), Philosophy and Learning. Universities in the Middle Ages, E.J. Brill, Leiden 1995, p. 137-199. Ver ainda os volumes de actas: Knowledge and the Sciences in Medieval Philosophy. Proceedings of the Eight International Congress of Medieval Philosophy (SIEPM). Helsinki 24-29 August 1987, 3 vol., Helsinki 1990; Cl. LAFLEUR - coll. J. CARRIER (eds.), L'enseignement de la philosophie au XIIle siécle...; e O. WELJERS - L. HOLTZ (eds.), L'enseignoment des disciplines à la Faculté des arts (Paris et Oxford, XIIle-XIVe siècles). Actes du colloque international (Studia artistarum, 4) Brepols, Turnhout 1997 (deste volume apenas pude consultar as estudos de Ch. Lohr e A. Maierủ, por amável comunicaçăo dos respectivos autores).

7 Também é longa a bibliografia sobre o impacto das condenaçôes de 1277 na prática filosćfica, embora se encontram poucos elementos sobra a influência nas práticas institucionais, remeto apenas para L. BIANCHI, II vescovo e $i$ filosofi. La condana parigina nel 1277 e l'evoluzione dell'aristotelismo scolastico (Quodilibet, 6) P.L. Lubrina, Bergamo 1990, que dá uma ampla bibliografia anterior; e A. de LIBERA, Penser au Moyen Age (Chemins de pensée), Ed. du Seufl, Paris 1991, cap. IV-VII. Sobre o controlo do saber e as condenações anti-aristotélicas e anti-filosóficas ao longo do século XIII ver os estudos de L. BIANCHI, "Censure, liberté et progrès intellectuel à 
partir desta data que rareiam e praticamente desaparecem os textos de elogio e divisâo da filosofia e, po isso, conviria clarificar porque é que a literatura de elogio e divisão da filosofia prolifera entre estes dois factos: as proibiçōes iniciais de ler publicamente os livros naturais de Aristóteles e a grande condenação de 1277 de teses reais ou fictícias ensinadas em Artes. As "introduçōes à filosofia" fazem precisamente sentido no quadro dos novos cursos universitários, aos quais fornecem uma verdadeira ideologia do valor da ciência e indirectamente da dignidade do Mestre, embora em grande parte sejam anónimos ou com identidades difusas, o que de certa forma testemunha quer o carácter escolar, compilatório e quase colectivo destas obras, quer a relação directa com o sistema de ensino nas universidades e com as formas de avaliação aí em uso. ${ }^{8}$

De qualquer modo, estes textos são apontamentos destituídos de interesse visto que, para além de preciosas informaçōes sobre a vida universitária, discutem ou estão na origem de novas abordagens da ciência de um modo sistemático, nomeadamente sobre a delimitação do seu objecto, os modos de relação entre ciências, os métodos gerais e particulares de demonstração usados, o que justifica bem o interesse que lhes tem sido dedicado.

Rapidamente a prática universitária do século XIII alterou a tradição grecoromana de estruturação do ensino sobre as sete artes liberais, passando a centrálo na leitura e comentário de obras cujos títulos constituiam os programas de estudos. ${ }^{9}$ Sabemos que neles não constava uma disciplina introdutória e geral que exigisse um manual ou livro de revisões e memento, ou da qual resultasse a composição dessas obras, o que legitimamente faz colocar a pergunta: em que prática escolar têm origem esses textos introdutórios? Devemos encarar os manuais como resultado de um trabalho e criatividade individuais sobre a organização e os conteúdos da filosofia, apesar de este tema não estar lectivamente autonomizado? Tudo indica que não. Uma parte substancial dos textos universitários sobre a divisão das ciências são o resultado das primeiras lições dos mestres de Artes no inicio dos seus cursos de leitura das obras curricularmente prescritas, sobretudo de Aristóteles. ${ }^{10}$ Temos um exemplo no prólogo Triplex est principium do comen-

l'université de Paris au XIIle siècle", Archives d'histoire doctrinale et littéraire du Moyen Age 63 (1996) 45-93 e "Les interdictions relatives à l'enseignement d'Aristote au XIIIe siècle", in Cl. Lafleur - coll. J. Carrier (eds), L'enseignement de la philosphie au XIIle siècle..., obra cit., p. 109-137.

8 Sobre a finalidade das introduçōes à filosofia e dos guias do estudante ver C. LAFLEUR, "Les 'Guides de l'étudiant' à la Faculté des arts...", p.175-177; O. WEIJERS, Le maniement du savoir..., p. 27-32 e 196.

9 Os programas de ensino nas faculdades de Artes são analisados cap. 1 da obra de O. WEIJERS, Le maniement du savoir. Partiques intellectuelles à l'époque des premières universités (XIIIe-XIVe siècles), (Studia artistarum, Subsidia) Brepols, Tumhout 1995, p. 9-23. Indicaçōes gerais sobre o ensino da filosofia também se podem encontrar em A. KENNY - J. PINBORG, "Medieval Philosophical Literature" in N. KRETZMANN - A. KENNY - J. PINBORG (eds.) The Cambridge History of Later Medieval Philosophy, Cambridge University Press, Cambridge 1982, p. 11-42, em especial p. 12-19; no mesmo volume é estudado o impacto da recepção de Aristóteles sobre as concepções e a prática da filosofia: Ch. LOHR, "The Medieval Interpretation of Aristotle", p. 80-98.

10 O. WEIJERS, Le maniement du savoir..., obra cit., p. 30-32 e 192. De qualquer forma, o interesse pela divisão das ciẻncias não se confinava às faculdades de Artes, também os mestres da de Teologia eram conduzidos ao tema, por exemplo quando comentavam o De Trinitate de Boécio e aí encontravam uma classificaçăo da filosofia (a mais ampla reflexão de Tomás de Aquino sobre o 
tário aos Tópicos de Adenunfo de Anagni e em diversos outros escritos que possuem no seu final resumos de obras ou de áreas disciplinares concretas, como acontece com a Philosophia de Nicolau de Paris ou mesmo o "Guia do estudante" de Paris, que dedica cerca 144 parágrafos ao louvor, definição e divisão das três partes da filosofia e os restantes 1131 parágrafos às ciências da linguagem. ${ }^{11}$ Também o proémio do comentário de Pedro de Hibernia sobre o Peri hermeneias é uma commendatio philosophiae que propõe uma divisio scientiae para mostrar que a lógica, não sendo uma parte da filosofia pode ser considerada como tal. ${ }^{12} \mathrm{Em}$ todos os casos e devido a problemas como o discutido por Pedro de Hibernia, o método de divisão e classificação das ciências pervade o discurso dos mestres insinuando-se por todo o lado e não apenas nos textos especificamente dedicados ao tema. ${ }^{13}$

Os comentários de obras de Aristóteles que resultam de cursos abrem geralmente com textos de fundamentação, enquadrando essa obra como uma ciência no âmbito geral das ciências e identificando o seu objecto e o seu método de demonstração próprios. Veja-se o exemplo das obras sobra a alma, que encontramos sob duas formas literárias distintas: os manuais compostos fora do âmbito cursório e os comentários que resultam directamente de lições proferidas. Nos manuais não existe qualquer discussão sobre a natureza e utilidade da ciência da alma, as suas dificuldades, a natureza epistemológica dos seu objecto ou da relação com as outras ciências, entra-se imediatamente na explicação da res. ${ }^{14}$ A situação é bem

estatuto e as divisōes das ciências pode ler-se justamente no seu comentário desta obra, cujas questōes 5 e 6 se centram na divisảo e nos métodos das ciências especulativas), ou quando utilizavam o tema com uma intenção de reforma escolar e edificação moral (como Boaventura na $R e$ ductio artium ad Theologiam) ou como metáfora (também Boaventura no Intinerarium mentis in Deum III, 6). Sobre o problema da divisăo das ciências entre os teólogos ver G. DAHAN, "Les classifications du savoir..." p. 11-12. Também em na Faculdade de Medicina a classificaçăo das ciências constituís um problema introdutório no programa de leitura de obras; a propósito da obra médica de Pedro Hispano, cfr. S. NAGEL, "Artes, scientiae e medicina nel comento al De animalibus di Pietro Hispano", Bulletin de philosophie médiévale 38 (1996) 53-65.

11 Para as referências destes textos ver a n. 5. Sobre o "Guia do estudante" parisiense ver o plano geral na ediçăo citada, p. 325-327, em Cl. LAFLEUR, "Les "guides de l'étudiant de la faculté des arts...", art. cit., p. 178-182 e no final da introduçăo do vol. Cl. LAFLEUR - coll. de J. CARRIER (eds.), L'enseignement de la philosophie au XIIle siècle..., op. cit, p. xiv-xvil.

12 Magistri PETRI DE YBERNIA, Expositio et quaestiones in librum Aristotelis Peryermenias seu de interpretatione (ex cod. Vaticano latino 5988), ed. by M. DUNE (Philosophes médiévaix, 34) Ed. Peeters, Louvain 1996, p. 3-8.

13 A título de exemplo veja-se a solução da questão De aeternitate mundi de Boécio de Dácia estru. turada sobre as três cièncias especulativas (ed. J.G. Pedersen, Boethil Daci Opera, CSDMAE vol. 6/2, Hauniae 1976, p. 335-366) e as classificaçōes das cièncias em obras de Rogério Bacon (ver o vol. J. HACKETT, ed., Roger Bacon and the Sciences. Commemorative Essays, STGM 57, E.J. Brill, Leiden 1997 e em especial o estudo de J. HACKETT, "Roger Bacon and the Classification of Sciences", nas p. 49-65).

14 A titulo de exemplo vejam-se o De anima de Gundissalino ainda do séc. XII (ed. J.T. Muckie, Mediaeval Studies 2, 1940, 23-102) e do século XIII: o anónimo De potentil animae et obiectis (ed. D.A. CAL.LUS, Rech. de Theól. Anc. et Méd. 19, 1952, 131-170), o anónimo De anima et de potenciis eius (ed. R.-A. GAUTHIER, Rev. des Sciences Philo. et Théol. 66, 1982, 3-55), de Joăo de La Rochelle o Tractatus de divisione multiplici potentiarum animae (ed. P. MICHAUD-QUANTIN, Vrin, Paris 1995) e a Summa de Anima (ed. J.-G. BOUGEROL, Vrin, Paris 1995), a Scientia libri de anima de Pedro Hispano Portugalense (ed. de M. ALONSO, Obras de Pedro Hispano I, Juan Flors ed., Barcelona $1961,2^{\mathbf{a}}$ ed.). 
diversa nos comentários sobre o De anima, a começar por aquele que aqui nos ocupará, onde os problemas filosófico-epistemológicos são o ponto de partida de todas as discussões, muito para lá do que a letra do primeiro capítulo da obra de Aristóteles incitava a dizer. ${ }^{15}$ Neste aspecto, os comentários sobre o De anima (e o mesmo se poderia dizer sobre os de outras obras de Aristóteles) parecem depender das "Introduções à filosofia" e das "Divisões da filosofia" mas falta um estudo comparativo geral que fundamente esta ideia. Poderá bem acontecer o contrário e serem os "manuais" e "guias do estudante" a recolher e epitomizar as discussões que se encontram nos comentários e resultam das efectivas discussões lectivas, embora certamente estas devam algo às próprias "introduções à filosofia".

O Commentarium in de Anima atribuido a Pedro Hispano ${ }^{16}$ poderia dar-nos algumas pistas sobre a origem e a intencionalidade daqueles manuais. De facto, ao longo das suas páginas vão aparecendo observações e argumentos relacionados com a questão da divisão das ciências, mas sem a mesma sistematização que os manuais tinham por objectivo oferecer.

Seguindo um hábito que se repete nos cursos universitários, o autor começa pela teorização ou justificação da possibilidade de conhecimento do seu objecto de estudo, discutindo também o lugar que ocupa no quadro das ciências. As conhecidas palavras de abertura do De anima valorizam o conhecimento sobre a alma, atribuindo-lhe um estatuto prioritário em razão da certeza que atinge e da superioridade do seu objecto e pelo seu contributo para o conhecimento da verdade em geral ("O conhecimento é, na nossa opinião, uma coisa bela e admirável ... / Bonorum honorabilium noticiam opinantes ...”, I 1, 402a1-5), mas Pedro nāo se limita a uma análise literal do texto de Aristóteles e inscreve antes do Comentário

15 A $1^{2}$ liçăo da Sententia cum questionibus in de anima do "anónimo de Gauthier", que tem múltiplas relaçōes com o comentário atribuído a Pedro Hispano, tem também implícita uma classificaçăo das ciências, cfr. Anonymi Magistri artium, Lectura in librum de anima a quodam discipulo reportata (Ms. Roma Naz. V.E. 828), ed. R.-A. GAUTHIER, (Specilegium bonaventurianum, 24) Ed. Coll. S. Bovanturae ad Claras Aquas, Grottaferrata 1985, p. 1-14, sobre a dependència face ao comentário de Pedro ver p. 17* e o índice na p. 508. Já da segunda metade do século veja-se o inicio dos três textos publicados por M. GIELE - F. VAN STEENBERGHEN - B. BAZÁN (eds.), Trois commentaires anonymes sur le traité De l'âme d'Aristote (Philosophes médiévaux, 11) Publications Universitaires - Béatrice-Nauwelaerts, Louvain - Paris 1971. Mesmo o comentário de Tomás de Aquino, o primeiro dos seus comentários aristotélicos e realizado na intenção do seu trabalho de teólogo, se faz eco destes problemas, embora de um modo mais limitado à letra do texto do De anima (ed. R.-A. Gauthier, Sancti Thomae de Aquino Opera Omnia 45/1, Comissio Leonina - Lib. philo. J. Vrin, Roma - Paris 1984).

16 PEDRO HISPANO, Comentário al "De Anima" de Aristóteles (Obras Filosóficas II), Ed., introduc. y notas M. ALONSO, Consejo Superior de Investigaciones Cientificas, Madrid, 1944 (784 p., comentário nas p. 59-768). A ediçăo de Alonso baseia-se no único manuscrito entảo conhecido (Kraków, BJ, 726, ff. 41r-134r). Mais tarde seria identificado um segundo apografo (Venezia, BNM, Lat. Z 253 , ff. $54 \mathrm{r}-99 \mathrm{r}$ ), também incompleto. Sobre as diferenças entre ambos ver os artigos de Cruz Pontes citados na nota 18. Em outro lugar avancei a hipótese de este comentário năo ter sido escrito pelo Pedro Hispano Portugalense autor da Scientia libri de anima, nem pelo Pedro Hispano autor das Summulae logicales ou Tractatus. As diferenças doutrinais e de estilo indiciam que estamos perante vários autores. Convirá ainda dizer que nesse estudo sugeri que nenhum destes três autores é o Pedro Jullão que veio a ser papa entre 1276 e 1277 sob o nome de Joăo XXI. Cfr. J.P. MRIRINHOS, "Petrus Hispanus Portugalensis? Elementos para um diferenciação de autores", Revista Española de Filosofia Medieval, 3 (1996) 51-76, sobretudo as p. 67-71 e 75-76. 
três problemas preambulares, compostos por questōes ${ }^{17}$ sobre o conteúdo, os limites e as interdependências da ciência da alma e outras questōes de método. Desta discussão extrai-se uma peculiar estruturação das ciências, centrada na comparação dos respectivos objectos e métodos de demonstração, bem como das relações que as ciências mantém entre si quanto aos mútuos contributos e à máxima realização do saber. Qual é, entâo, a classificação das ciências que podemos extrair do Comentário e de que modo o autor lida com a questão epistemológica da ciência da alma? ${ }^{18}$

A forma literária do Comentário sobre o De anima indica-nos que é certamente o resultado de lições cursórias, ${ }^{19}$ do qual não conhecemos a totalidade do texto. ${ }^{20}$ Cada lectio é constituída por dois regimes discursivos paralelos: a "intensio auctoris" que constitui uma explicação contínua da letra do texto aristotélico, ${ }^{21}$ desdobrada em (1) citaçăo lematizada do De anima juntamente com a sua contextualização no plano da obra, (2) a "divisão do texto", divisio textus, (3) resumo da divisão, divisionis recollectio, (4) afirmaçōes conclusivas, sententiae philosophi, que correspondem à identificação das posições de Aristóteles; o segundo instrumento discursivo são as questiones, geralmente apresentadas como um aprofundamento explicativo do que antes foi afirmado e que nos transportam para lá do texto e por vezes o aproximam de doutrinas năo aristotélicas (por ex. em I, 1: "Ad maiorem evidentiam predictorum quinque questiones incidunt inquirende", p. 184, 18-19). Esta organização do texto levou R.-A. Gauthier a observar justamente que

17 Bm geral as questōes têm a estrutura habitual (pergunta, razōes pró e contra, solução, resposta às razóes), mas por vezes revestem a forma de simples quesitos (pergunta e solução). A estrutura da argumentaçăo năo é constante, umas vezes a soluçăo segue as razŏes a favor outras segue as razōes contra, vejam-se como exemplo as qq. 4 e 5 do Problema 3: no primeiro caso a solução assenta nas rationes e responde aos argumentos em contrário (q. 4, p. 117-119), no segundo caso sustenta a solução nos argumentos em contrário e refuta as rationes (q. 5, p. 119-122).

18 A classificaçăo e definiçăo das ciências em outras obras atribuídas a Pedro Hispano, em especial as médicas, já foi tratada de modo minucioso por Silvia NAGEL em várias ocasiōes: "Antropologia e medicina nei Problemata di Pietro Ispano", Medioevo 17 (1991) 231-148; "Scienze de rebus e discipline de vocibu..." p. 108-111; "Artes, scientiae e medicina nel commento al De animalibus..." art. cit.

19 Sobre esta obra, ver em especial os trabalhos de J.M da Cruz PONTES: A obra filosófica de Pedro Hispano Portugalense. Novos problemas textuais (Série de Cultura), Instituto de Bstudos Filosóficos, Universidade de Coimbra, Coimbra 1972, em especial as p. 117-158, dedicadas a este comentário; "Les Questiones libri de Anima de Petrus Hispanus Portugalensis", Mediaevalia Philosophica Polonorum, 19 (1974) 127-139; “Un nouveau manuscrit des 'Questiones libri de anima' de Petrus Hispanus Portugalensis", Recherches de Théologie Ancienne et Médiévale, 43 (1976) 167-201. Para uma contextualização na filosofia naturalistica de Pedro Hispano, ver ainda J.M.C. PONTES, Pedro Hispano Portugalense $e$ as controvérsias doutrinais do século XIII. A origem da alma, Instituto de Estudos Filosóficos, Universidade de Coimbra, Coimbra 1964.

20 Com ligeiras diferenças entre os dois manuscritos, o texto termina ex abrupto nas questōes da lição 11 do livro II (relativa a De anima II 4, 415b7-415b28, portanto sem chegar a melo da obra de Aristóteles) sem que se possa saber se a parte final se perdeu ou se 0 autor interrompeu neste ponto o seu trabalho.

21 Note-se que cada liçāo começa com a expressăo “continuatio intensionis" (expressão que o editor colocou nos títulos) e em geral a síntese das sentenças do filósofo termina com uma expressão do tipo "et sic manifestatur intensio huius partis" (cfr. por exemplo a lectio I 1, p. 181, 7 e p. 184, 17), as questōes vêm após essa frase. 
estamos perante o tipo de obra então designada como Sententia cum quaestionibus, sugerindo que constituirá um curso dado talvez (peut-être) na Universidade de Toulouse, por volta de 1240.22

As questōes das duas primeiras lições do livro I, as questões da quarta lição do livro II e outros textos ocasionais, abordam problemas de natureza epistemológica e metodológica, mas os três "Problemas preambulares" são exclusivamente dedicados a esses temas: "Sobre os assuntos que são determinados ${ }^{23}$ na Ciência da alma, questionam-se principalmente três [problemas]: o primeiro é a determinaçăo do objecto (de stabilitate subiecti) da ciência da alma e da necessidade (necessitas) desta ciência; o segundo é a comparação (de comparatione) desta ciência com as outras ciências; o terceiro é sobre o modo de proceder (de modo procedendi). ${ }^{24}$

\section{1 - Possibilidade de uma ciência da alma}

No primeiro problema preambular, ${ }^{25}$ logo na solução da questão $1,{ }^{25} \mathrm{o}$ autor articula as múltiplas razões pelas quais a ciência da alma é necessária. As duas primeiras coincidem com as palavras de Aristóteles no início do De anima: a nobreza do objecto e a certeza do conhecimento e em segundo lugar o auxilio que presta às outras ciências e sobretudo às ciências naturais tomam necessária a ciência da alma. Em terceiro lugar porque é útil para outras ciências, nomeadamente para a ciência moral (scientia moralis) e a ciência do governo da cidades (scientia de regimine civitatum), citando o "comentador" defende ainda que é útil para a teologia (theologia), porque "pela ciência da alma se conhecem as potências da alma necessárias para o conhecimento dos hábitos teológicos", ${ }^{27}$ A quarta

22 GAUTHIBR, R.-A.: "Notes sur Siger de Brabant, II. Siger en 1272-1275. Aubry de Reims et la scission des normands", art. cit. acima na n. 5, p. 11; e "Introduction", in Sancti Thomae de Aquino, Sententia libri de anima (pp: 1*-294*). Opera Omnia, t. XLI,1. Comissio Leonina-Libr. Philos. J. Vrin, Roma-Paris 1984 , p. $239^{*}$ b (cfr. $239^{*}-241^{*}$, sobre a data ver as p. $191^{\star}$ e $240^{*}$ ). Mas, recentemente Charles Lohr, sem contestar as hipoteses de Gauthier, cita diversas vezes o comentário de Pedro como exemplo da concepçăo de "scientia" na Faculdade de Artes de Paris após meados do século, cft. Ch. LOHR, "The New Aristitle and 'science' in the Paris Arts Faculty (1255)", in O. WEIJERS - L. HOLTZ (eds.), L'enseignement des disciplines..., 1997, p. 251-270.

23 A "determinatio" deve ser aquí tomada no seu sentido técnico de exercicio escolar que compete ao mestre na sua tarefa de concluir e solucionar os problemas colocados. Ao longo do comentário o mestre faz coincidir o conteúdo da determinatio com o conteúdo da ciência da alma. Sobre a determinatio como etapa das "quaestiones", cfr. O. WBIJERS, Terminologie des universités au XIIIe siècle, (Lessico intellettuale europeo, 39) Ed. de l'Ateneo, Roma 1987, p. 348-350.

24 Este texto é um curto prölogo das questōes preambulares, que o editor colocou como seu título geral, cfr. p. 59, 1-5.

25 O problema 1 é composto por 15 questōes (cfr. Comentário, p. 59-85), 8 das quais (a saber: qq. 1-2 e 10-15) serão repetidas no final do problema 3, com algumas diferenças textuais (cfr. p. 163-179). No ms. de Veneza o problema 1 é composto apenas por estas 8 questōes e não se verifica a repetiçăo do ms. de Cracóvia; cfr. J.M.C. PONTES, "Un nouveau manuscrit des Questiones...", art. cit., p. 185 e IDEM, Novos problemas textuais..., p. 134. As primeiras 4 questões encontram-se traduzidas em M.M. BERGADÁ, "Un comentário de Pedro Hispano al 'Tratado del Alma' de Aristóteles", Ciencia y fé (Madrid) 11-12 (1947) 86-107.

26 Comm. Probl. 1, q. 1, sol., p. 62.

27 De facto, aparte algumas diferenças terminológicas (com theologia no lugar de scientie divine), a terceira razão retoma Averróis, Comm. magnum in De anima, I 1, texto 2, Ed. Crawford p. 5, 24-29. 
e última razão é porque manifesta as operações da alma, porque se a sua substância é oculta (isto é, não poderá ser sujeito de sensação), as suas operações são manifestas nos animais, como afirma Aristóteles. Temos portanto que a dignidade do objecto, a certeza do conhecimento, a utilidade para o conjunto das ciências (que inclui as naturais, as morais e a metafisica) e por fim a possibilidade de a conhecer como manifestação, tornam possível e necessário o conhecimento sobre a alma. $\mathrm{O}$ primeiro argumento contrário à posiçăo de Pedro introduz o problema noético da origem e natureza do conhecimento da alma, que resulta da situação paradoxal de dela não podermos ter percepçăo sensivel, porque é uma substância espiritual e năo sensoriável, portanto não cognoscível, como exemplifica o aforismo "nada que não esteve primeiro nos sentidos pode ser inteligido / nichil quod non prius fuerit in sensu cadit in intellectu" (p. 61, 12-13). Pela resposta a esta objecção constatamos que há seis diferentes modos de demonstrar a possibilidade de conhecimento da alma, admitindo desde logo que de facto não há um conhecimento da alma "per speciem", a qual só pelas suas operaçōes "cadit in sensu" e portanto poderá também ser indirectamente inteligida. Paralelamente, aceita a possibilidade de um conhecimento intuitivo da alma, baseando-se aqui em Algazel (Metaphysica III, ed. Muckle, p. 64-65) e em Dionísio pseudo-Areopagita (passim), mas também em autores como Agostinho (aliás, no De spiritu et anima), Ibn Gabirol ou Boécio (Consolatio philosophiae), citados nas questões seguintes que tratam o problema da natureza, inata ou adquirida, do conhecimento da alma. Pedro admite, desde a q. $2,{ }^{28}$ a dupla origem do conhecimento da alma, que pode ser ou "a suo creatore a quo exit", que é um conhecimento inato de si mesma e do bem futuro, mas "non est cognitio scientifica ipsius anime", e o conhecimento das coisas mundanas, adquirido por fantasmas, e por isso é "cognitio scientifica", não inato mas adquirido. ${ }^{29}$ Portanto, é apenas no conhecimento "per speciem" que se funda a possibilidade de constituição de uma ciência da alma, porque, embora indirectamente, dela podemos ter conhecimento representacional (per speciem) e por isso poderá ser objecto de definição e demonstração, elementos indispensáveis a todo o conhecimento verdadeiro e certo. A possibilidade de abstracção cognoscitiva da "species" das coisas mostra a inteligibilidade do real e constituiu o fundamento da doutrina coerencial do conhecimento que envolve o universal, o intelecto e as coisas. ${ }^{30}$

${ }^{28}$ Pedro resume a via platónica e a via aristotélica, que partilha, de aquisição do conhecimento, Comm. Probl. 1, q. 2, sol., p. 65, 23-66, 24: "Ouidam posuerunt quod anima creatur perfecta scientiis et virtutibus. (...) Alil posuerunt quod anima cognoscit per acquisitionem solum. Set quidam illorum posuerunt res corporaliter acquiri in anima; alii autem posuerunt res spiritualiter acquiri in anima, scilicet per species; et sic posuit Aristoteles, sicut patet. In 'de' anima enim posuit quod anima non haberet cognitionem sibi innatam set acquisitam et hec acquisitio spiritualis est." As questões seguintes (qq. 3-9, p. 67-73) ocupam-se do problema do auto-conhecimento da aima, por presença de si e não através da espécie sensivel, cfr. J. MORBAU, "Pedro Hispano et le problème de la connaissance de l'âme", Arquivos de História da Cultura Portuguesa, 1, fasc. 3 (1967) 3-9.

30 Sobre a noética petrínica e a função representacional da "species rerum" abstraf́da, que actualiza a conformidade entre o intelecto e as coisas, ver o Coment. I, 11, qq. 1-6, p. 389-406, ver abaixo $\mathrm{n}$. 67; para uma breve análise dessas questōes ver L. SPRUTT, Species intelligibilis: From Perception to Knowledge. I, Classical Roots and Medieval Discussions (BSIH, 48) E.J. Brill, Leiden 1994, p. 132-134. 
Esta cortante divisão entre cognitio scientifica e non scientifica suscita uma análise dos diversos sentidos com que Pedro usa o termo scientia, única forma de podermos identificar o que se pretende com a indagação do que é a "ciência" da alma. No texto atrás citado scientia significa: (1) o conhecimento pelo conceito e demonstrável, que é sempre adquirido e representacional; é neste sentido que há uma ciência ou conhecimento da alma que se funda na species adquirida por abstracção a partir dos seus actos. Mas, em outros usos scientia também indica (2) a obra de Aristóteles ou o objecto que nela se encontra delimitado e descrito, como quando diz: "actor [i.e. Aristóteles] in scientia ista [i.e. De anima] prius incipit a substantia..." (p. 234, 28), ou, por exemplo, que o De sensu et sensato é sequente "ad scientiam De anima et ordinata ad ipsam" (p. 102, 16-21). Scientia remete ainda para (3) um conjunto distinto de conhecimentos que se identifica com uma determinada área do saber e é neste sentido que se pode de falar de divisão das ciências segundo princípios. Os três sentidos diversos de scientia são unificados sob o conceito de subjectum (objecto) ou conteúdo sobre o qual a ciência versa. É na sobreposição destes diferentes sentidos que para Pedro há uma ciência da alma, e não tanto no sentido moderno de conjunto de procedimentos que possibilitam a descoberta e prova de novos factos e estados de coisas. ${ }^{31}$

Voltemos aos dois regimes de conhecimento, inato ou adquirido, que parecem ter o seu equivalente numa certa distinção entre dois modos opostos de considerar a alma, por um lado no seu estado de separaçâo do corpo e enquanto substância espiritual, por outro lado enquanto unida ao corpo e nele existente enquanto forma ${ }^{32} \mathrm{~A}$ alma enquanto substância considerada sem a sua ligação ao corpo em razão da sua espiritualidade (de anima separata prout a corpore extrahitur, p. 167, 23 , expressão que não se encontra na versão da p. 74), pode ser objecto de ciência e de conhecimento (Probl. 1, q. 10, sol., p. 74, 24-25) da Metafisica, sob três pontos de vista: o primeiro corresponde à ontologia, "methaphysica" em sentido aristotélico-aviceniano de estudo do ente, ou estudo da alma enquanto ente, do seu estado, do seu ser e da sua vida separada. O segundo modo corresponde a uma moral especulativa, "scientia moralis", ou "scientia de felicitate", ou "scientie de puris animabus", segundo a terminologia de Macróbio, ${ }^{33}$ porquanto se pode também considerar a alma enquanto frui da felicidade pelas virtudes adquiridas no corpo e pelas quais a alma alcança a felicidade. Em terceiro lugar, a alma enquanto separada pode ser considerada na sua união ao criador e pela fruição da visão do seu criador e enquanto para ele se ordena como as outras substâncias espirituais e

31 O conceito de scientia é central na recepção de Aristóteles pelos mestres de Artes do séc. XIII, que assim colhem a tradição aristotélica arabizada, em especial a interpretação de Averrơis. Ver por exemplo Ch. LOHR, "The New Aristotle and 'science' in the Paris..." em especial as p. 260266 , onde se citam passagens do Comentário de Pedro; veja-se na p. 264 a fórmula de Tomás de Aquino, In I poster. anal., lect. 44, ed. Leonina, p. 320a: "Scientia importat certitudinem cognitionis per demosntrationem acquisitam", que coincide bem com o uso (1) de Pedro.

Cfr. p. $78,5-15$, p. $78,29-79,4$, p. $81,28-30$, etc. Embora Pedro esteja a determinar o modo de estudo da alma em geral, na primeira citaçâo Pedro refere-se concretamente à alma intelectiva: "Dicendum est quod dupliciter est loqui de anima intellectiva: uno modo a parte sue substantie et vite separate (...). Alio modo (...) de anima a parte unionis corporis". Mas, neste contexto, não volta a ser feita referência ao intelecto.

33 Parece haver aqui uma remissăo para Macróbio, Commentarí in Ciceronis somnium Scipionis, I, 8. 
este aspecto compete à "Theologia" ${ }^{34}$ Mas, importa concluir que fica liminarmente excluída da ciência natural, que é a que aqui importa a Pedro, o estudo da alma enquanto separada ou sem relação com o corpo (p. 81, 28-30).

A alma enquanto "unida ao corpo e quanto à sua existência no corpo, na medida em que tem operações comuns com o corpo" diz respeito à ciência natural: "esta ciência da alma que é objecto da presente especulação, é [uma ciência] natural, porque é sobre a alma unida ao corpo". ${ }^{35}$ Esta conclusão obriga a uma clarificação, requerida pela própria estruturação do corpus aristotélico, que Pedro vê como um todo orgânico sem contradições nem repetições, é que se diversas obras se ocupam do corpo animado e dos seres dotados de alma torna-se necessário clarificar de que aspectos particulares é que cada uma se ocupa e qual é a mais importante. Assim, o objecto do De anima é o corpo animado no seu todo enquanto se refere à alma e às operações da alma, o De vegetalibus ocupa-se das partes e das disposições do corpo animado e o De animalibus ocupa-se do corpo animado quanto à sua complexão e às disposições das suas partes. ${ }^{36}$ Portanto, a ciência da alma ocupa-se de todas as faculdades da alma (p. 83, 11-12), rejeitandose a posição, então mais difundida, daqueles que defendem que a ciência da alma se ocupa do corpo animado pela alma intelectiva, ${ }^{37}$ que a ciência dos animais é sobre o corpo animado pela alma sensivel e a ciência das plantas é sobre o corpo animado pela alma vegetal (pp. 82, 32-83, 11). Pedro rejeita a restrição do âmbito de cada uma das obras, mas introduz uma classificação geral das ciências do corpo animado cujo conteúdo distribui por três áreas: em primeiro lugar a complexão do corpo e da disposição das suas partes, sua origem e morte como se encontra no De vegetalibus e noDe animalibus; a segunda área diz respeito às operações do corpo animado com origem na alma e termo no corpo e encontra-se no $D e$ anima; a terceira diz respeito às operações com origem e termo no corpo animado, abrangidos pelos Livros menores: De sompno et vigilia, De morte et vita, De inspiratione et respiratione). Mas, reitera Pedro, a ciência da alma, o De anima, abrange a alma como um todo e o conjunto das suas faculdades e não apenas a

34 Comm. Probl. 1, q. 11, sol., p. 76, $12-33$ (repetída nas p. $169-170$ ), cfr. p. $78,6-7$, p. $78,29-79$, 4, p. 81, 28-82, 2, etc.

35 Comm. Probl. 1, q. 12, sol., p. 78, 5-15.

36 Comm. Probl. 1, q. 13, sol., p. 81, 10-23. A soluçāo desta q. clarifica os seis modos segundo os quais se pode falar do objecto de uma ciência, oportunidade, para identificar também o objecto da Methaphysica (p. 80, 20-81, 2) e o da Rethorica (causa vel questio civilis e oratio rethorica), Logica (sillogismus) e Grammatica (oratio) devendo notar-se que estas últimas très constituem as partes da philosophia rationalis ou sermocinalis scientie do "Guia do estudante" parisiense, cfr. Cl. LAFLEUR - coll. J. CARRIRR (eds.), Le "Guide de l'etudiant d'un maitre..., obra cit., \$̧\$ 145, 154, 503.

37 Como mostrou R.A. Gauthier, esta era a tese corrente em Paris no final da primeira metade do séc. XIII, contra a qual Pedro, seguindo Averróss, năo confina a ciência da alma à faculdace intelectiva, gando-a ao estudo da alma como um todo e integrando-a orgånicamente nas ciências do corpo animado, posiçăo que terá alguns seguidores nos anos seguintes, cft. R.-A. GAUTHIER, "Notes sur Siger de Brabant, II. Siger en 1272-1275. Aubry de Reims...", art. cit., p. 8-15 e "Introduction", in Sancti Thomae de Aquino, Sententia libri de anima, ed. cit. na n. 22, p. $240^{\circ}-241^{*}$. Convém apenas assinalar que Pedro Hispano năo estabelece explicitamente uma ordem entre estas obras/ciências e que a ciência das plantas é colocada depois da dos animais e antes da da alma. Sobre a ordem de dignidade de cada uma destas ciências, que é inversa da ordem pedagógica, veja-se abaixo a n. 52 . 
intelectiva ${ }^{38}$ Portanto, a ciência não se ocupa da alma enquanto forma substancial separada, mas da alma enquanto forma do corpo (forma corporis), aliás esta é a única ciência individual que se ocupa de uma só espécie de forma e da sua matéria que é o corpo (q. 15). Esquematizando, poderiamos fazer o seguinte resumo das

\section{Ciências que se ocupam da alma}

Alma enquanto substância separada (a parte suae substantie et vite separate): Metaphysica

- [Ontologia]: a alma enquanto ente, seu estado, ser e vida separada

- Scientia de felicitate / Scientie de puris animabus: a alma enquanto frui de beatitude

- Theologia:: a alma enquanto se une ao criador e pode fruir da sua visăo

Alma enquanto unida ao corpo (a parte unionis eius in coprpore): Scientia naturalis

- De vegetalibus e De animalibus: complexão do corpo e disposição das suas partes

- De anima: operaçóes da alma com origem na aima e termo no corpo (o corpo animado enquanto se refere à alma e às operaçōes da alma)

- Minores libri: operações do corpo animado com origem e termo no corpo

Claramente Pedro retira o De anima do âmbito da metafísica e coloca-o no coraçẫo da ciência do corpo animado. Este corte não deixa de ter consequências, obrigando a confrontar repetidas vezes a ciência da alma com a metafisica, o que nos fornece muitos elementos sobre a sua concepção da filosofia primeira. Ao discutir os modos como algo pode ser "subiectum" de uma ciência, encontra-se uma caracterização da Metafísica como ciência do que é efectivamente separado, ${ }^{39}$ que é algo diferente da que aqui se propõe para esse objecto particular que é a alma enquanto considerada como separada. De facto, a Metafísica engloba: "Deus" (como "illud indivisibile ad quod reducuntur et a quo fluunt omnia"), o "ens inquantum ens" (como "illud commune per predicationem communem ad omnia"), a "substantia" ("illud in quo radicantur omnia").40 Dai que possamos dividir a Metafisica em três ciências particulares:

\section{Metaphysica}

Scientia diuina vel Theologia; subjectum: Deus

Metaphysica [- Ontologia]; subjectum: ens inquantum ens

Metaphysica [= Ousiologia]; subjectum: substantia

De facto Pedro colhe de forma difusa alguns dos elementos da discussão, profunda e prolongada do seu tempo, a propósito do estatuto e do objecto da Metafísica, exibindo perspectivas que excedem a própria Metafisica de Aristóteles ao conciliar perspectivas provenientes de autores como Avicena (focalizando a

38 Comm. Probl. 1, q. 14, ad 2um, p. 83, 25-84, 15 (repetida nas p. 177-178). A mesma doutrina encontra-se no Probl. 2, q. 1, sol, p. 88, 1-19.

39 “(...) Sicut ponit Aristoteles [Metaph. VI 1, 1026a11-32], status rerum triplex est. (...) Alie autem sunt res separate a motu et materia omnino et secundum esse et secundum diffinitionem et tales sunt de consideratione Methaphysice" Probl. 2, q. 11, $1^{2}$ ratio, p. 75, 14-21.

40 Cfr. Comm. Probl. 1, q. 13, sol., p. 80, 20-81, 25; sobre o objecto da Metafísica e o seu corpus literário ver também I 1, q. 1.1, p. 186-189 e as n. 75 e 94 mais à frente. 
Metafísica no ente enquanto ente), Averróis (a substância), o Liber de causis e talvez Gazali (o fluxo do Deus criador).41

A grande conclusão do primeiro problema preambular é que as ciências se distinguem pelo seu subjectum e pelo modo como o consideram..$^{42}$ Até à questão 13 ficara estabelecido que é possivel um "conhecimento científico" da alma, ou seja adquirido e demonstrável e assim constituir uma ciência natural que se ocupa do corpo animado. Depois de a distinguir do modo como a Metafisica se pode ocupar da alma, considerando-a na sua separação substancial do corpo, confrontaa com as restantes ciências naturais; dentro destas encontrámos referências às que se ocupam do corpo animado, objecto por sua vez dividido em três modos particulares de subsistência natural, a que correspondem outros tantos grupos de obras aristotélicas ou pseudo-aristotélicas. A não ser em alguma argumentação lateral, não se encontra aqui qualquer recurso à teoria da abstracção, nem aos respectivos métodos de conhecimento, dois dos mais recorrentes principios de distinção entre as ciências, sobretudo a partir de meados do século XIII. ${ }^{43}$ São os conteúdos empiricos (determinados pela definição do objecto de cada ciência) e as obras (quase todas da constelação aristotélica, cada uma sobre conteúdos particulares), que até aqui servem de critério de distinção das ciências.

\section{2- A ciência da alma face às ciências naturais}

A ciência da alma partilha com outras o mesmo objecto? Como pode, então, constituir uma ciência diversa? A "comparação desta ciência [da alma] com as outras ciências naturais"44 permite responder ao problema da subalternação das ciências. Trata-se também aqui de delimitar o subjectum (objecto), matéria e conteúdo da ciência da alma, discutindo aspectos de fronteira que poderiam suscitar ambiguidade, colocando a ciência da alma na dependência de outras ciên-

41 As complexas variantes da constituição do objecto da Metafisica no âmbito latino envolvem aristotelismo e peripatetismo, com contributos mais ou menos conscientes e profundos de neoplatonismo, cfr. A. de LIBERA, La philosophie médiévale (Que sais-je? 1044), PUF, Paris 1993, p. 70-78 e o seu estudo mais desenvolvido: "Structure du corpus scolaire de la métaphysique dans la première moitié du XIIle siècle", in Cl. Lafleur - coll. de J. Carrier (eds.), L'enseignement de la philosophie au XIIIe siècle..., obra cit., p. 61-88, cfr. p. 61-seg.

42 Sem dar uma definição de subjectum, na soluçăo que visa determinar que a ciência da alma se ocupa "do corpo animado enquanto se refere à alma e às operações da alma", Pedro identífica seis modos como algo pode ser subjectum de uma ciência (Probl. 1, q. 13, sol., p. 80-81). Na terminologia escolástica subjectum pode significar o substrato, mas nesta utilização significa aquilo que uma ciência conhece, suas propriedades, a definição ou demonstração, por essa razão o termo pode em português contemporâneo ser traduzido por "objecto" (uma vez que "sujeito" é habitualmente reservado para designar aquele que conhece). Por sua vez objectum significa o objecto proprio de um órgão ou de uma faculdade e que por isso a toma passivel de actualização. A distinçăo das ciências a partir dos respectivos objectos de estudo (subjecta) é uma caracteristica das classificações de Avicena princípio esse que foi incorporado por Gundissalino no De divisone philosophiae (ctr. H. HUGONNARD-ROCHE, "La classification des sciences de Gundissalinus ...", art. cit., p. $47,51-52,54$ e n. 105,60 ) e a partir dai se toma doutrina corrente no Ocidente, combinada com a tendência, especialmente visivel em Averróis, em fazer uma ciência particular de cada obra de Aristóteles.

Cfr. B.-H. WBBBER, "La classification des sciences selon Avicenne a Paris vers 1250", art. cit., p. 88-seg.

44 Cfr. p. 87, 1. 3. O segundo problema preambular é composto por 20 questōes. 
cias. Mais uma vez, o principio que parece orientar Pedro é que cada género de ser deve ser tratado por uma ciência diferente. Mas, paradoxalmente, Aristóteles ocupa-se do corpo animado em diferentes livros e em alguns deles ocupa-se das mesmas questōes. Torna-se necessário anular e explicar esta aparente incongruência. Nas questōes 1 a 13 e 15 a 18 do segundo problema, Pedro procura explicar porque é que um mesmo objecto é tratado em diferentes ciências. As questōes 14 e 20 revestem-se de grande interesse metodológico sendo explicativas da distinção entre ciências e das divisōes internas de cada uma.

Retomando alguns temas antes aflorados, Pedro começa por considerar o corpo animado e a alma que é a sua forma, que por envolveram muitas coisas, são tratados de modo diverso no $D e$ animalibus, no Liber vegetabilium, ${ }^{45}$ no $D e$ anima, nos Minores libri (De sensu et sensato, De morte et vita, De sompno et vigilia), a mesma doutrina que encontrámos duas questões antes (cfr. Probl. 1, q. 14), acrescentando-se que a diferença das ciências nasce da diferença dos seus principios. ${ }^{46}$ Mas, por outro lado, numa só ciência, isto é a da alma, são tratadas todas as faculdades da alma (in eadem scientia determinatur de omni differentia anime, p. 88 , 12-13), embora no De vegetalibus seja tratada de modo especial a vegetativa e no De animalibus a sensitiva. Este problema é resolvido com a introdução do conceito de relação ou "comunidade no objecto" (communicantia in subiecto), ou seja a vegetativa, a sensitiva e a racional exercem as suas operações no corpo em que existem, "assim, há comunidade em todas estas faculdades da alma e porque a comunidade no objecto, proporciona unidade na ciência é uma mesma ciência da alma que se ocupa de todas as faculdades da alma" ${ }^{47} \mathrm{O}$ mesmo conceito de "communicantia" justifica o não tratamento do corpo vegetal na ciência da alma, porque não tem um princípio comum, ossos e carne, que såo a "communicantiam physicam" entre o corpo do animal e o do homem e por isso no De anima a vegetativa e a sensitiva são tratadas em conjunto. ${ }^{48} \mathrm{~A}$ fórmula "communicantia in subiecto facit unitatem in scientia" sublinha a intima ligação do objecto e a delimitação de cada ciência e clarifica o modo de relação entre ciências que se ocupem do mesmo objecto. Pedro procurará nas obras de Aristóteles a distinção ou a communicantia que podemos encontrar na alma como forma do corpo animado.

A delimitação dos conteúdos particulares dos livros de Aristóteles, desde logo tomados como ciências, que se ocupam do corpo animado, suas propriedades, actos e afecções, é o tema central da seguinte série de quesitos. ${ }^{49} \mathrm{Em}$ todos os casos se trata de estabelecer a matéria da ciência da alma e mais concretamente do De anima, face ao outros livros aristotélicos, embora num ou outro caso haja também referências a disciplinas sobre as quais a enciclopédia aristotélica é omis-

$45 \mathrm{Em}$ outro local Pedro refere como equivalentes os dois títulos sob os quais corria o tratado de botânica pseudo-aristotélico, dizendo que sobre as plantas se determina "in Libro plantarum vel Vegetabilium, quod idem est" (p. 97, 18-19).

46 Comm. Probl. 2, q. 1, sol., p. 88, 1-25.

47 Comm. Probl. 2, q. 2, sol., p. 89, 22-90, 15.

48 Comm. Probl. 2, q. 3, sol., p. 90-91. A "communicatio in subiecto" desempenha um papel central na distinção entre ciências em Avicena e em Gundissalino, cfr. HUGONNARD-ROCHE, "La classification des sciences...", art. cit., p. 47 e n. 57, p. 54 e n. 106.

49 De facto, a forma literária destas questōes é simplificada: contêm apenas a pergunta $e$ a soluçăo, sem razōes pró e contra, năo havendo por isso lugar às respectivas respostas. 
sa. Não sendo possível analisar aqui em pormenor cada uma das razões pelas quais Pedro explica que um mesmo assunto é tratado em diferentes ciências/obras, baste referir que essas razōes são múltiplas, por exemplo se algo é tratado como objecto de uma faculdade ou órgão (objectum), ou como meio (medium), ou como disposição (dispositio) ou como relação (relatio ad), ou como princípio (principium), ou como causa, ou pela sua geração (generatio), etc. Cada uma destas razōes pode combinar-se com outras, ou dividir-se em vários modos de ser considerada. $\mathrm{O}$ mesmo arsenal de argumentos serve para clarificar a näo existência de obras de Aristóteles sobre cada um desses assuntos particulares que são partilhados entre várias ciências. Vejamos os casos das ciências que tratam assuntos que se encontram também no De anima.

A começar repete-se que os Libri minores e o De anima constituem ciências diferentes porque aqueles tratam das operações da alma que apenas provêm do corpo e por isso têm um princípio que os distingue da Ciência da alma, que determina sobre as operações da alma que provêm da alma (Probl. 2, q. 4, pp. 91-92). Porque o crescimento ("augmento") pode ser considerado de duas formas, o De anima determina sobre ele de modo diferente do De generatione et corruptione (Probl. 2, q. 5, p. 92). Também a cor pode ser considerada de três formas, daí as diferenças a seu respeito entre o De sensu et sensato, i.e. como resultado da natureza perspícua e das quatro qualidades, o De anima, i.e. como objecto que modifica a vista, e a Medicina, ${ }^{50}$ i.e. como signo de saúde ou doença (Probl. 2, q. 6 , pp. 92-93). A voz é objecto de múltiplas abordagens: no De animalibus, no $D e$ anima, na Música, na Gramática, na Medicina e no De sensu et sensato (Probl. 2, q. 7, p. 93). Aliás, a dupla origem dos objectos (i.e., o que altera os corpos ou os sentidos) permite explicar porque é que a voz é tratada não só no De sensu et sensato, mas também no De anima (Probl. 2, q. 8, p. 93-94); a pergunta aqui formulada tem uma segunda parte ilustrativa: querendo saber porque é que "[Aristóteles] nem fez um tratado especial sobre ela [a voz]", Pedro está a denunciar que a determinação do conteúdo das ciências se pode também resolver pela clarificação da intencionalidade literária de Aristóteles. O sabor e odor são tratados de modo diverso no De sensu et sensato, no De anima, na Medicina e no De vegetabilibus (Probl. 2, q. 9, p. 94-95). Também as quatro qualidades tangiveis são abordadas sob diversos modos no De generatione et corruptione, no livro IV dos Meteora, na Medicina, no De anima, de tal modo que não é necessário que no De sensu et sensato exista um tratado exclusivo sobre o tacto (Probl. 2, q. 10, 95-96).

A intencionalidade de Aristóteles é ainda explorada na questão 11, de um modo justificatório: se Aristóteles no De anima começa por estudar o sentido da visão, embora nessa obra defenda que o tacto é o primeiro sentido pelo qual o animal vive e portanto por ele deveria começar, é porque o objecto da visão (a cor)

50 Pedro refere a Medicina junto a títulos de obras e não é claro se está a referir-se a alguma obra ou à ciência médica em geral, ou se evoca a suposta Medicina de Aristóteles, referida por exemplo no anónimo de Gauthier: "et de tall in medicina Aristotelis, qua utuntur Greci, et hec nobis deest" (Anonymi magistri artium, Lectura in librum de anima..., ed. R.-A. Gauthier, obra cit., p. 3, 74-75). Apenas num caso surge o título de uma obra médica, na pergunta "Iterum cum de plantis determinetur in Libro vegetabilium et in Medicina in Dietis queritur quo modo differenter" (p. 97, 11-13), mas năo sabemos se se refere a um dos tratados de Isaac, às Dietas universais ou às Particulares. 
é comuníssima a todos os corpos e é simplicíssima, enquanto que o tacto é mais material e grosseiro e por isso é determinado em último lugar. Por outro lado, como no De anima os sentidos se ordenam para o conhecimento, a visão é tratada em primeiro lugar porque por ela conhecemos mais coisas (Probl. 2, q. 11; p. $96-$ 97). Os animais e as plantas também são tratados sob diferentes ângulos na ciência natural (no Livro dos animais e no Livro das plantas) e na Medicina (Probl. 2, q. 12 , p. 97). A morte e a vida são tratadas num grupo mais largo de obras, segundo diferentes perspectivas: no De anima, no Liber mortis et vitae, na Astronomia, ${ }^{51}$ na Medicina (Probl. 2, q. 13, p. 97-98).

A questão 14 interrompe esta série de comparações, para enfrentar o problema da organização ou hierarquia das ciências do corpo animado, procurando saber qual das três é prioritária. Como, a prioridade diz respeito ou ao plano da ciência ou ao plano das coisas, a ciência da alma é a prioritária no plano da ciência: "a primeira causa é pela nobreza do seu objecto. A segunda é pela certeza da demonstraçăo. A terceira causa é que o objecto desta é caúsa de todas as coisas que são determinadas nos livros sobre as coisas animadas e todas são por causa da alma. A quarta causa é o auxilio que presta a todas as outras; de facto proporciona (influit) certeza a todas as outras ciências e as suas conclusōes (dicta) devem ser supostas nas outras ciências." Também quanto à coísa, há uma dupla ordem: "De facto na via da geração e da constituição simples (incomplexionis) há um antes, e assim a matéria é anterior à forma. $\mathrm{E}$ assim a ciência dos animais e a dos vegetais precedem esta [da alma]. Mas, há uma outra prioridade na via da organização (complexionis) e da perfeição e da nobreza e da dignidade. Assim, a forma precede a matéria e a alma o corpo. E, assim, esta ciência da alma, pela parte das coisas (a parte rerum) precede as outras referidas" ${ }^{52}$ Portanto, para Pedro, quer no plano da ciência, quer no plano da ordem das coisas a ciência da alma é prioritária, mas a ressalva da prioridade na ordem das coisas, permite sustentar a tese já defendida antes que "a ciência dos animais e a dos vegetais é anterior a esta", o que fundamentará sobretudo a sua anterioridade pedagógica face à ciência da alma.

Falta agora determinar a relação de ordem da ciência da alma com a dos pequenos livros naturais. Assim, "ao contrário do que outros pensam", após a ciência da alma vem o De sensu et sensato e só depois o De memoria et reminiscentia, que constitui uma ciência distinta da da alma. ${ }^{53}$ Aliás, os livros menores formam ciências separadas porque tratam de operações que têm origem no corpo e por isso se distinguem das que têm origem na alma e são tratadas na sua ciência, embora, ressalva o mestre, nem todas as operações da alma dêem origem a ciências separadas. ${ }^{54} \mathrm{~A}$ propósito de operações que não dão origem a uma ciência separada Pedro dá-nos o interessante exemplo do movimento dos animais que é tratado no livro $\mathrm{Da}$ alma, mas tudo o que diz respeito à relação do movimento com os órgãos e às disposições dos animais que o executam é tratado "in libro (...)

51 De facto, trata-se da Astrologia porquanto refere a influência dos astros no retardamento ou prolongamento da vida (p. 98, 6-10).

52

53 Comm. Probl. 2, q. 14, sol., p. 100, 8-23.

Comm. Probl. 2, q. 15, 100-103.

54 Comm. Probl. 2, q. 16, 103:104. 
quem facit Aristoteteles De motibus animalium qui non est in latino." O autor sabe que Aristóteles compôs esta obra, ${ }^{55}$ embora afirme que não foi traduzida para latim, o que só aconteceu por volta de $1266 .{ }^{56}$

Também as operações da alma intelectiva não originam uma ciência separada, porque estão apenas relacionadas com a alma e por não acrescentarem outras disposições ou principios à ciência da alma, são tratadas nesta de modo completo..$^{57}$ Regressam, a seguir, as comparações entre ciências, explicando-se porque é que as potências sensitivas são tratadas de modos diferentes no De anima, no De sensu et sensato, no De naturis animalium, na Medicina. ${ }^{58}$ Por fim indaga-se porque é que no livro II do De anima são tratadas a alma vegetativa e a sensitiva e no III a intelectiva: as primeiras são acto de certas partes do corpo e devido a essa communicantia pertencem ao mesmo tratado. Como a "intelectiva é mais espiritual e não é acto de alguma parte do corpo", é tratada numa parte diferente da obra. ${ }^{59}$

A última questão do problema 2 é metodológica, indagando qual "a causa da distinção entre ciências e das partes da ciência entre si" ${ }^{60}$ As causas da diversidade são múltiplas e provêm quer do objecto, quer das coisas que o integram. Em primeiro lugar 0 objecto de uma ciência distingue-se do de outra pelo género de abstracção: "tal como a coisa unida ao movimento e à matéria se distingue da coisa totalmente separada da matéria e daquela que está unida segundo o ser e separada segundo a definição" (p. 106-107). A diferença do género de abstracção "produz a diversidade das definiçōes nas ciências principais, como por exemplo nas partes principais da filosofia". Claramente Pedro refere-se à doutrina de inspiração aristotélica de divisão entre as três principais ciências Metafísica, Matemática, Ciências naturais, com base na teoria da abstracção. A segunda causa de diversidade, pelo modo de subalternação, ocorre pela adição de dísposições de outra natureza ao objecto (a linha visual acrescenta outro principio à linha em si), também se pressupōe aqui a doutrina geral, num exemplo também muito repetido, que toma a ciência da linha visual como subalternada/subalterna, da ciência da linha em si, que é a subalternante. A terceira diferenciação diz respeito às partes do objecto principal de uma ciência, por adjunção das suas propriedades e afecções, da qual advém "a separação dos livros principais", cada um dos quais se ocupa de afecções particulares, que estão na origem da "diversidade dos capítulos". A quarta causa da diversidade é a que resulta das diferentes conclusōes e afecçōes que se comprovam em cada parte do objecto, "de onde resulta a distinção de parágrafos". Esquematizando, verificamos que Pedro expõe os principios de divisão das ciências, apontando para um modelo hierarquizador:

55 A sua fonte é certamente Averróis, que também não possuía a obra, Commentarium Magnum in Aristotelis De anima libros, III 54, ed. F.S. Crawford, p. 524, 59-61.

56 Bssa traduçăo foi realizada por Guilherme de Moerbeke cerca de 1266, cfr. J. BRAMS, "Guillaume de Moerbeke et Aristote", in J. HAMESSE - M. FATTORI (ed.), Rencontres de cultures dans la philosophie médiévale, Université Catholique de Louvain - Università degli Studi di Cassino, Louvain - Cassino, 1990, p. 317-336, cfr. p. 320, 331.

57 Comm. Probl. 2, q. 17, p. 104.

58 


\section{Modo}

Bstado das coisas

Disposiçōes e afecçōes

Partes do objecto principal adiçăo de propriedades

Partes das partes abstraç̧ão

subalternaçẵo

conclusões sobre cada parte

\section{Diversidade por Origina a}

divisẫo das 3 partes principais da filosofia separação entre ciências da mesma espécie diferença de livros e de capitulos nos livros distinçăo de parágrafos no interior da ciência

Estão aqui condensados os princípios nos quais se baseia a instituição do estudo da alma enquanto ciência, que pertence a uma das 3 partes principais da filosofia, mais concretamente à ciência natural ( $1^{\circ}$ modo de divisão). Dentro destas, a ciência da alma é subaltemante, pois dos seus principios dependem várias outras, que analisam aspectos particulares do seu objecto ( $2^{2}$ modo de divisão), o qual é analisado em diferentes livros, nomeadamente as obras de Aristóteles sobre os seres animados, os quais por sua vez abordam parcelar e progressivamente o seu objecto ( $3^{\circ}$ modo de divisåo). Por sua vez, cada obra ou scientia é constituida de conclusões apresentadas em parágrafos ( $4^{2}$ modo de divisão). Se os dois primeiros modos justificam quer a inserção num quadro geral e a autonomia da ciência da alma, o terceiro e quarto modos justificam a técnica de divisão de texto (partes, capítulos, parágrafos e sentenças) em que se baseará o comentário e o método de exposição das conclusões ou sentenças do filósofo que, como vimos, constitui a primeira parte de cada uma das liçōes do Comentário. ${ }^{61}$

Pedro conclui esta enumeração de princípios explicando que "esta distinção da ciência nas referidas partes (diversitates) não decorre de uma exigência da nossa exposição (traditionis nostre), mas de uma exigência das coisas e do estado e da razăo da ciência". ${ }^{62}$ Para Pedro a ciência, enquanto conjunto de livros, é um espelho da natureza, a qual è a única razão da divisão das ciências embora permaneçam um todo orgânico, visto que cada ciência, cada livro, cada parte, cada capitulo, cada parágrafo corresponde a uma particularidade do que existe. A homologia entre a ciência e a natureza é constantemente reafirmada com fórmula como: "sicut est in natura, ita est in scientiis" (I 1, q. 3, sol., p. 219, 23-24 = p. 157, 26-26); Como exemplificava Aristóteles, a ciência, isto é o que se sabe, deve dividir-se de acordo com a divisão ou estado das coisas: "Secantur igitur scientia et sensus in res", ${ }^{3}$ tese repetida por Roberto Kilwardby como fundamento da divisăo das ciências: "scientia (...) dividi debet secundum divisionem rei de quibus est."

61 Uma recapitulação das principais divisôes do De anima pode ser lida no início da liçăo 1 do livro II: o De anima divide-se em duas partes principais: o proémio (I 1) e a parte executiva (resto da obra), esta divide-se em duas partes: opiniōes dos outros filósofos acerca da alma (I 2-5) e determinaçẵo sobre a alma segundo o método da verdade (II-III), também o segundo tratado se divide em duas partes, que ainda se bifurcam sucessivas vezes em partes, capítulos, parágrafos e sentenças, cfr. Comment. II, 1, p. 489-494.

62. Cir. p. 107, 23-26. Como vimos acima, o status rerum explica os três modos de abstracção e a divisâo das três principais ciências especulativas.

63 De anima, 431b24-25, transl. a Jacobo Veneto, od. Gauthier (Anonymi, Lectura in librum De antma..., obra cit., p. 484); a trad. arabo-latina é mais descritiva: "Dicamus igitur quod scire et sentire dividuntur secundum divisionem entium" (AVRRROIS, Commentarium magnum in de anima, a Michele Scoto transl., ed. Crawford, p. 305); trad. do grego por B. BARBOTIN (Les Belles Lettres, Paris 1980, p. 86): "On sait que science [episteme] et sensation se divisent de la mème manière que leurs objets". $\mathrm{O}$ acordo entre o inteligido e o seu objecto é sublinhado por Aristóteles em ou- 
A ordem das coisas (exigentia rerum) fundamenta a ordem literária da ciência (status scientie et ratione ipsius). Inversamente, este principio fundamenta a estratégia hermenêutica do Mestre de Artes, que faz e descobre a ciência partindo da de um texto para encontrar as coisas. Ao interpretar as obras de Aristóteles, penetrando na intenção do autor (porque é que trata determinado assunto, como o faz, com que objectivo o faz, porque é que o faz naquele lugar) o intérprete está já a compreender a natureza das coisas. Ao longo do comentário de Mestre Pedro, a dilucidação da intentio auctoris em cada lição vai precisamente nesse sentido. Compreender Aristóteles equivale a çompreender as próprias coisas, as quais por sua vez justifica porque é que foram tratadas nesta ou naquela obra. Fecha-se assim um circulo hermenêtico em que numa primeira operação se mostra que a divisăo das ciências, a ordem e conteúdo dos livros equivale à própria estrutura da natureza e a seguir deve concluir-se que interpretar e aprofundar o conteúdo dos livros equivale a compreender a natureza das coisas.

\section{3 - Os métodos da ciência da alma}

O terceiro problema preambularef e em especial as questōes da primeira lição tratam o problema do método de demonstração da própria ciência da alma.

Desde logo só pode haver conhecimento certo e demonstrado dos universais. Os singulares são infinitos e sem estabilidade (infinita instabilia et non fixa), por isso a ciência não poderá ocupar-se deles mas sim do que é estável e delimitado (fixo finito et stabili) e este apenas o é porque há o universal que é "incorruptivel, pelo qual o próprio singular permanece uno e estável". Mas, como no conhecimento ele não é dado a priori, torna-se necessário estabelecer que as ciências precisam da abstracção e qual dos quatro modos de abstracção thes é mais adequado. Na ciência da alma, como em qualquer outra ciência, há abstracção do universal (para tudo isto ver a $1^{\mathfrak{a}}$ razão da questão 1. p. 109, 4-13). 0 primeiro dos seus modos é "a abstracçảo do universal a partir do particular e é segundo este modo que esta ciência e qualquer ciência natural abstrai" ${ }^{66}$ Peđro adopta a indu-

tros locais do De anima: $430 \mathrm{a2}-5$ (identidade do sujeito e do objecto na inteleç̧ăo e da ciência teórica e do seu objecto), 431a1-2 (identidade da ciência em acto com o seu objecto),

64 Robert Kilwardby, De ortu scientianum, ed. cit., III 5, p. 10 e X 40, p. 23.

65 O problema 3 tem uma organizaçăo anómala, pois após a questão 5 é anunciada uma questão 6 com múltiplas divisōes (cfr. p. 122, 3 - 123, 2). Note-se desde já que no mansucrito de Veneza este actescento não se verifica e o problema 3 é apenas composto pelas cinco primeiras questōes editadas por Alonso, todas relativas à abstracçăo (p. 109-122). 0 grupo de questōes acrescentadas (que seriam a $6^{a}$ questẳo subdividida em vảrias outras) coincide com as questōes da $1^{a}$ e $2^{a}$ liçôes do livro I e, por isso, eståo af editadas de novo (p.184-207). Como no inicio do problema eram anunciadas 15 questōes (ctr. p. 109, 3) e perante uma provável lacuna no seu exemplar, o copista terá repetido no final do terceiro problema preambular algumas questōes que faziam parte das liçōes do Comentário. Sobre as ciferenças entre o ms. de Cracóvia/ediçẫo Alonso e o ms. de Veneza, ver ainda J.M.C. PONTES, “Un nouveau manuscrit des Questiones...”, p. 185-186 e DEM, Novos problemas textuais..., p. 134-138. As questôes repetidas por antecipaçăo pertencem de facto às liç̋̃es 1 e 2 e assim serão apresentadas.

66 Comm. Probl. 3, q. 1, sol., p. 111 (ver também I 7, q. 3, ad 1am rat., p. 314, 9-26 que tem algumas lacunas de transcriçāo). Neste mesmo texto se sintetizam cutros très modos de abstracçăo: $2^{\circ}$ ) a abstracção da forma a partir da matéria ("abstractio forme a materia"), que é própria das ciências 
Ção cognoscitiva proposta nos Segundos analíticos II 19, para explicar a abstracção do universal a partir do particular. ${ }^{67} \mathrm{O}$ conteúdo da ciência resulta da abstracção realizada pelo intelecto através de um acto cognoscitivo, mas porque é que ele pode ocorrer e porque é que este modo particular de abstracção é possivel? é-o em razão da alma ou das coisas? A necessidade da abstracção é dupla, por exigência das coisas e por exigência da alma cognoscente. De facto, nas coisas existe a "espécie simples da própria coisa" (simplex species ipsius rei) que é aquilo que é abstraído e que faz com que a coisa seja o que é, que move a alma segundo o seu estado e disposiçōes e estabelece uma proporcionalidade entre as coisas e a alma, porque as coisas "são entes e são cognosciveis e assim possuem algo pelo qual sã̃o o que são e pelo qual são conhecidas". ${ }^{68}$ Pedro não deixa qualquer espaço para a preexistência das formas e do universal no intelecto humano e coloca a abstracção na base do processo de intelecçâo ou constituição do universal enquanto inteligivel. Portanto quer a natureza da coisa, quer as disposições do intelecto são causa da abstracção, que conjuga a conformidade que há entre ambas por intermediação da espécie.

Para uma extensa série de razōes pró e contra a questão sobre o fundamento da abstracção Pedro dá uma resposta muito curta porque passa a sua fundamentação para os argumentos a favor: o principio da abstracção é a forma e a espécie do universal e é por esta que há conhecimento: "Esse autem in rebus esta a forma. Ergo, vera cognitio rei est a forma que dat esse. Hec autem est forma esse universalis". 69

Falta apenas pormenorizar que o modo de abstracção próprio das coisas naturais é o da abstracção do universal a partir do particular, repetindo mais uma vez

matemáticas que se ocupam da quantidade abstracta; $3^{2}$ ) a separaçăo (separatio) das coisas e do movimento e matéria, como é o caso das substâncias espirituais separadas, e desta abstracção se ocupa o metafisico; $4^{\circ}$ ) "a acepçăo das espécies a partir dos sensiveis segundo a sua representaçăo pela faculdade intelectiva" e este é o modo de abstracção próprio do conhecimento. (Os três primeiros modos de abstracçåo, ques estăo na base das distinçāo das três principais ciências especulativas, sảo referidos, por exemplo, no final da soluçăo do art. 3, q. 5 do Super Boetium de Trinitate de Tomás de Aquino). A matemática, porque se ocupa da quantidade tem o privilégio de usar a abstracção própria de todas as ciências e ainda o segundo modo de abstraç̧ấo, cfr. Cornm. Probl. 3, q. 2 sol., p. 112-113. A diferença entre a abstraç̧ão cognoscitiva e o terceíro modo de abstracçăo (que remete para a teoria das substâncias espirituais separadas enquanto objecto da metafisica) tem raiz alfarabiana e influenciou subretudo a primeira escolástica, cfr. A. de LIBERA, La querelle des universaux de Platon à la fin du Moyen Age, (Des travaux) Bd. du Seuil, Paris 1996, p. 110-seg.

67 Cfr. a $2^{a}$ ratio, p. 109, 14-20. A abstracção cognoscitiva é mais incisivamente descrita noutro local: "(...) abstractio est multis modis. Uno modo est abstractio specierum per virtutes anime ab ipsis rebus secundum quam abstractionem sensus abstrahit species sensibiles et ymaginato accipit eas a sensu et intellectus ab ymaginatione et hec abstractio via esta ad cognitionem", Comm. I 7, q. 3, ad lam rat., p. 314, 10-15.

68 Comm. Probl. 3, q. 3, sol., p. 116, 17-33. O Mestre anuncia no final da soluçăo que a espécie simples enquanto principio de inteligibilidade será tratada depois, como de facto acontecerá em I 11 , qq. 1-6, p. 389-406, ver acima n. 30 .

69 Probl. 3, q. 4, p. 117-119, o texto citado é da $3^{a}$ ratio, p. 118, 11-14. A quarta ratio (p. 118, 23-30) introduz a denudatio algazeliana com o mesmo sentido de abstracção ou despojamento das condiçỏes acidentais que permite ao intelecto conhecer a própria essência das coisas, cfr. Algazel's Metaphysics IV 5, ed. Muckler, p. 172-seg. 
que o seu modo próprio não é a separação, como no caso da Metafísica, nem a abstracção da forma a partir da matéria, como na Matemática. ${ }^{70}$ Portanto, a abstracção própria das ciências naturais é uma contracção material ("contractio materialis", p. 121, 13), pela qual se conhece de modo certo o ser universal de uma dada natureza. A certeza e o conhecimento científico, apenas são possiveis pela abstracção, um processo intelectivo pelo qual o "universale in rebus" ou "in multis" é mimetizado em "universale in intelectu" ou "in anima". A onto-noética, com o phantasma e a species, é o verdadeiro plano de resolução do problema do conhecimento que distingue as ciências naturais que, por não poder ser senão conhecimento do universal, depende da abstracção entendida como processo gnosiológico próprio da alma. Embora essa fonte não seja citada, Pedro mantém presente o núcleo da argumentação de Aristóteles sobre a abstracção enxertada nos elementos de gnosiologia do final dos Analíticos posteriores (II, 19). A forma inteligivel ou universal abstraído é necessário para o conhecimento dos entes naturais e por isso é entendido como princípio formal da intelecção e da ciência enquanto conhecimento necessário e verdadeiro do seu objecto. Não deve deixar de ser sublinhado que com a possibilidade de o conhecimento certo e verdadeiro ocorrer só através do universal abstraído, portanto conhecido a posteriori, Pedro reitera a exclusão de uma origem quer inata, quer intuitiva, quer iluminativa do conhecimento universal. Mais uma vez, é a Ciência da alma que permite explicitar os próprios fundamentos do conhecimento e portanto de qualquer ciência.

Termina aqui o texto de que dispomos para o problema preambular 3 , embora lhe faltem 10 das 15 questões anunciadas e em seu lugar apresente duas séries de questōes que de facto pertencem às duas primeiras lições do comentário onde são editadas de novo (cfr. acima n. 65).

Entradio no Comentário, Pedro não se mostra satisfeito com as conclusões dos problemas preambulares e a questão da natureza da ciência da alma, da sua relação com as outras ciências e do seu método volta a ser colocada, por sugestão do próprio início do De anima de Aristóteles, cujo cap. 1 enuncia as aporias e perplexidades que podem servir de ponto de partida ao estudo da alma. ${ }^{71}$ São as célebres palavras do início do De anima que suscitam o requestionamento da natureza da ciência da alma. ${ }^{72}$

Pedro na primeria questảo da lição 1 compara a ciência da alma "com as outras ciências superiores e inferiores em razão da excelência de nobreza e de priori-

70 Probl. 3, q. 5 sol, p. 121. Sobre as várias exposições quanto à abstracção do universal em meados do séc. Xill ver E.-H. WEBER, "Abstractio", Les notions philosophiques. Dictionnaire, vol. 1, p. 9 11 (Encyclopédie philosophique Universelle, II), PUF, Paris 1990 e o estudo referente ao periodo posterior por J.F. BOLER, "Intuitive and Abstractive Knowledge", in N. KRETZMANN et al. (eds.) The Cambridge History of Later Medieval Philosophy, ed. cit., p. 460-478.

71 Pedro dedica exactamente 7 liçōes ao cap. I, 1 (p. 181-315) a que explicitamente chama proémio do De anima, cujo tratado I só começaria no cap. 2; sobre a divisão do texto ver acima n. 61.

72 Nesta lição há 5 questões, mas a questão 1 divide-se em 6 outras (1.1. a 1.6.), a questão 3 em 4 quesitos (3.1 a 3.3.) e a questão 5 em outros 3 quesitos (5.1. a 5.3.). Uma tradução das questões desta lição (cujo texto, com ligeiras diferenças de pormenor, é o mesmo da primeira parte da q. 6 do problema preambular 3, p. 122-150) encontra-se em António Soares PINHEIRO, "Pedro Hispano. Primado da Psiconoética", Revista Portuguesa de Filosofia 45 (1989) 569-584. 
dade”, chamando à discussão a Metafísica, a Matemática, a Física, a Cosmologia, a Moral e a Lógica. ${ }^{73}$

Saber se a ciência da alma é prioritária e mais nobre que a Metafísica obriga a uma longa série de razões e a uma soluçăo também longa onde se historiam diversas posiçōes quanto ao problema. ${ }^{74}$ Após de referir a posição de "alguns" e a de Averróis (que faz da ciência da alma a mais digna das ciências, exceptuando a "scientiam Divinam", Com. magn. in de anima I 1 texto 1, ed. Crawford p. 4, 3233), Pedro concilia as várias posiçōes, mas rompendo com elas num ponto importante, admitindo que a Metafísica é prioritária porque se ocupa do objecto mais geral (o ente) ou superior (Deus), ${ }^{75}$ mas também a ciência da alma é prioritária porque se ocupa do objecto (i.e. a alma) sem o qual não há conhecimento do que quer que seja, nem mesmo do objecto da metafisica. ${ }^{76}$ Também quanto ao modo de demonstrar (a parte modo demonstrandi) há duplicidade de nobreza, assim a Metafísica é mais nobre e anterior porque procede por causas superiores e é regra de todas as outras ciências influenciando-as (razões 1 e 2, p. 186, 20-28), mas a ciência da alma também é mais nobre na medida em que procede pelo que é anterior quanto à natureza e é mais conhecido para nós (i.e. os obiecta das potências são-nos conhecidos como causas, enquanto as substâncias separadas apenas são conhecidas pelos seus efeitos), porque o seu objecto lhe é imediato e nesta ciência há "identidade entre $o$ objecto e 0 que deve conhecer $o$ objecto e as suas afecções", e ainda porque ela "se ocupa dos principios de toda a certeza e sem os quais não há método (processus) na certeza” (razões 3 a 5, p. 188, 29-189, 13).

Chame-se desde já atenção para este aspecto do pensamento de Pedro, porquanto admite uma certa superioridade de estatuto da Metafísica enquanto ciência, ao mesmo tempo que reclama um lugar e uma função primordial da ciência da alma tendo em conta todos os outros critérios. Por razões estritamente gnosiológicas, que se prendem quer com o objecto, quer com o modo de demonstrar, quer com a primordialidade do próprio conhecimento, mas acima de tudo porque nela há coincidência entre cognoscente e conhecido, ${ }^{77}$ a ciência da alma ocupa um lugar nobre entre as ciências. É essa a ideia expressa no final da solução da questão que estamos a analisar: "Portanto, quanto ao estatuto de ciência (in statu scientie), a ciência metafísica é mais nobre e precedente; quanto ao outro estatuto (in statu alio) sobre o qual se falou, a ciência da alma é mais nobre" (p. 189, 14-16).

Comm. I 1, q. 1, p. 184-198, cit. p. 184, 19-22.

Comm. I 1, q. 1.1., p. 186, 22 - 189, 16, também no Probl. 3, p. 127-130.

75 Cfr. sol. raző́es 1 a 4, p. 186, 23-187, 25, a que se podem acrescentar as duas "rationes pro" sobre a superioridade da Metafisica: na $1^{2}$ ratio exprime-se o "ens inquantum ens" (aviceneano) e a geral latitude do ser (do Liber de causis, cap. 4) como objeto da Metafisica, a $2^{a}$ ratio faz-se eco da doutrina defendida por "diversos philosophos" sobre o triplo objecto da metafisica: Deus, a substância e 0 ente (p. 184-186). Esta apresentaçăo da Metafisica, quer quanto ao corpus textual aduzido quer quanto às ramificações doutrinais implicitas está próxima da do "Guja do estudante" parisiense, sobre o qual cfr. A. de LIBERA, "La structure du corpus scolaire de la métaphysique...", art. cit., 65-77. Sobre o objecto da Metafisica ver aqui nn. 40 e 94.

76 Cfr. sol. razões 5 a 8 (p. 187, 25-188, 19) e as 2 rationes ad oppositum (p. 186, 5-21).

7 Pedro pode basear-se aqui numa certa interpretação do argumento identitário boeciano da impossibilidade de a alma que conhece năo poder năo se conhecer a si mesma, cfr. Probl. 1, q. 3, sol., p. $68,17-25$ e $69,12-14$. 
Há em Pedro como que uma hesitação conciliatória entre a visão tradicional do lugar das ciências dentro de um sistema hiérárquico com preeminência da Metafisica e uma nova intuição da ciência da alma como ciência do homem, chamada a desempenhar um novo papel central fundamentador, quer quanto à natureza do conhecimento, quer quanto à relação entre as ciências, papel esse que não lhe é atribuido nem em Aristóteles, nem na tradição peripatética, nem em Averróis, nem no aristotelismo latino nascente, mas que lança alguns argumentos para a transformaçăo da gnosiologia em saber fudamental.

Vejamos como, a propósito das restantes ciências este lugar preeminente é reivindicado para a Ciência da alma, mesmo face às ciências tradicionalmente tidas como prioritárias e superiores, a saber a Metafisica, as Matemáticas e a Fisica (esta já pertencenđo ao mesmo género de ciência do ser natural). Embora certas posiçōes de intérpretes de Aristóteles relativizem a superioridade da ciência da alma, como Averróis que a considera apenas superior entre as ciências naturais, Pedro não hesita em contrariá-las dizendo que a Ciência da alma também é mais nobre que a Matemática pelas mesmas razões já aduzidas face à Metafisica, isto é quer quanto à nobreza do respectivo conteúdo, quer quanto ao modo de demonstraçăo, admitindo apenas que quanto ao principio de abstracção a Matemática é mais nobre porque procede por causas mais abstractas e mais próximas ao intelecto humano. ${ }^{78}$

A comparação com as ciências naturais nâo muda de tom, nem mesmo perante "a ciência dos livros das Fisicas" de Aristóteles. No que diz respeito ao objecto, a Fisica é anterior à Ciência da alma apenas se tivermos em conta a geração do corpo em si, que é anterior ao corpo animado; mas se tivermos em conta a perfeiçāo ou acto do corpo (a parte perfectionis et completionis) então já a Ciência da alma é prioritária, tanto mais que o seu objecto, "o homem ou a alma racional", é mais geral e é a razão final de tudo o que existe. Quanto ao modo de demonstração a ciência da alma é prioritária face à Fisica porque o seu modo de demonstração é mais certo, "embora pressuponha alguns princípios daquela" ciência física. ${ }^{79}$ A formulação é bem incisiva: "scientia de homine vel de anima rationali est nobilior qualibet scientia" e atesta a razão porque Pedro insiste na reserva de prioridade da Ciência da alma face a todas as outras..$^{80}$

Já por comparação com a Cosmologia, isto é com a "ciência Do céu e do mundo" de Aristóteles, a Ciência da alma é mais nobre quanto ao modó de demonstração e quanto ao objecto, aquela apenas tem o mérito de o seu objecto ser mais incorruptivel, tanto mais que "o homem é um objecto mais nobre [que o da Cosmologia] e a sua ciência, que é a ciência da alma, é mais nobre."'s1

78 Comm. I 1, q. 1.2., 190-191, idem no Problema 3, p. 132.

Comm. I 1, q. 1.3., p. 191-193, idem no Problema 3, p. 133-134. S. Nagel aproximou este texto de outro do Super Tegni Galeni de Pedro Hispano, onde se defende a superioridade da medicina sobre as cutras ciências porque o seu objecto é o mais nobre na sua natureza, a saber: o corpo humano, cfr. S. NAGEL, "Artes, scientiae e medicina...", art. cit., p. 62, n. 20.

81

Idem $2^{\mathbf{a}}$ ratio ad op., p. 192, 29-31.

Comm. I 1, q. 1.4., p. 194-195, idem no Problema 3, p. 135-136. 
Segue-se a comparação com a Moral. Pedro não a identifica com um livro particular, mas com três concepções diferentes: (a) como a ciência "que nos ensina de que modo teremos certas virtudes pelas quais nos unimos ao criador" e que é atribuída a Algazel (ratio 1 e 2); (b) como a ciência que nos ordena para o fim mais nobre e último, associada a Boécio (ratio 2), ${ }^{82}$ e por fim (c) como a ciência que versa os "actos da alma, que provêm da alma, enquanto nossas faculdades e operações", associada a Avicena (ad oppositum 1-2). Estas concepçōes parecem indicar que Pedro desconhecia as Éticas de Aristóteles. De qualquer modo, a ciência da alma é mais nobre quanto ao modo de proceder, porque "procede de um modo necessário e perfeitíssimo" e quanto ao objecto, porque a alma é a causa đas potências/virtudes (virtutum), que são o objecto da ciência da alma. ${ }^{83}$

Por fim é proposta a comparação com a Lógica, uma ciência da linguagem ("scientia sermocinalis quae est logica"). A Ciência da alma é em absoluto (simpliciter) mais nobre que a Lógica porque o seu objecto é mais nobre e porque realiza de modo mais perfeito o intelecto. Também para a Lógica fica uma diminuta superioridade, porquanto proporciona uma melhor disposição metodológica do intelecto para a inquirição da substância ${ }^{84}$ Repare-se nesta aproximação entre a ciência da alma e a lógica, ${ }^{85}$ que veremos ampliada na lição 2 do livro I para estabelecer uma separaçăo mais nítida a propósito do método demonstrativo da ciência da alma (que năo é fornecido pela Lógica mas pela Metafisica).

Concluida a comparação entre as ciências quanto ao objecto e ao método próprio de cada uma, Pedro resume os modos pelos quais advém certeza à ciência da alma, que procede pelo "modo mais certo" (modo certissimo), por três razōes: porque procede pelos primeiros objectos que no âmbito do conhecimento adquirido são os mais conhecidos para nós; porque o seu objecto é a alma e as suas faculdades, a qual é princípio e causa da certeza em qualquer ciência; porque nesta ciência há maior proximidade entre a alma que conhece e o que é conhecido que, acrescente-se, è a própria alma. ${ }^{86}$

Pedro retoma a questão do auxílio prestado às outras ciências, para reiterar que, "como diz o Comentador [Comm. magn. in De anima I 1, textos 1 e 2, ed. Crawford, pp. 4-5], a ciência da alma presta grande auxilio a todas as ciências e em primeiro lugar às naturais", desde logo porque é sua parte nobilíssima e por

82 Cfr. também p. 143, 8-10.

83 Comm. I 1, q. 1.5, 196-197, idem Problema 3, p. 138-139. Mas, admite Pedro, num aspecto a ciência moral é mais nobre: "porque ordena para um fim melhor".

84 Comm. I 1, q. 1.6, p. 197-198 (na linha 21 "substantiam" deve substituir "scientiam"), idem no Probl. 3, p. 139-140.

85 No estatuto da Faculdade de artes de Paris de 1255 o De anima podia ser lido em simultâneo ou com a lógica ou com os libri naturales, $O$. WEIJRRS, Le maniement du savoir ..., p. 11 e 49.

86 Comm. I 1, q. 2, sol. p. 199-200, idem no Probl. 3, p. 141-143. Como bem notou A.S. Pinheiro na sua tradução destas questōes (trad. cit., p. 579), Pedro explica a seguir quais os modos de excelência que Aristóteles não referiu à Ciência da alma. De facto, omitiu a nobreza de fim porque a ciência da alma é especulativa e năo é prática (q. 3.1, p. 201), assim como nāo mencionou a nobreza pela causa eficiente, que aliás só poderia ser identificada com ele próprio ou com Deus (q. 3.2, idem), nem a das afeç̧őes (q. 3.3, p. 201), nem quanto à causa formal senão pelo facto de, por ser ciência, esta ser idêntica ao modo de demonstração (q. 3.4, p. 202). 
que a alma é o princípio de todas as coisas animadas. Mas também auxilia a Moral oferecendo-lhe muitos principios, como os conhecimentos sensitivo e intelectivo, que são úteis para a regulação da cidade e das riquezas. Auxilia ainda as ciências demonstrativas, a Metafisica e a Matemática, proporcionando-Ihes o modo de abstracção e separaçăo, que procede da alma. Presta ainda um auxílio geral às ciências porque por ela se adquire o conhecimento dos primeiros princípios e das causas do conhecimento. ${ }^{87}$ Há quatro modos de interdisciplinaridade, ou de auxilio de uma ciência a outra, cada um dos quais é próprio de uma ciência particular, o que a torna superior às outras: (1) regular e dirigir o intelecto no modo de proceder em qualquer ciência, é próprio da Ciência demonstrativa (i.e., a Metafísica VII) que influencia todas as outras; (2) considerar e confirmar a substância dos princípios e do objecto mais geral que é o ser (ens), que em si compreende o de todas as ciências, por isso a Metafísica influencia todas as outras; (3) fornecer algo à ciência que lhe é inferior como, por exemplo, a Física influencia a Ciência da alma; (4) proporcionar o princípio da abstracção e o princípio da certeza, assim a Ciência da alma proporciona certeza a todas as outras. ${ }^{88}$

Na segunda lição, ${ }^{89}$ discute-se o método de definição adequado ao conhecimento da substancialidade da alma. As questōes da lição 2 do livro I, juntamente com as da lição 7 do livro I e as da lição 4 do livro II enfrentam justamente o modo (1) de "interdisciplinaridade", o que diz respeito ao método da demonstração e da definição substancial, sua inserção disciplinar, objecto, função e estrutura. O problema tem origem no próprio texto de Aristóteles onde, desde o cap. I 1 e o início do livro II, a busca de uma definição da alma tem um papel crucial na estrutura narrativa da obra. É necessário que exista uma ciência geral que ensine o modo de definir em toda a ciência geral e da qual qualquer ciência receba o modo de definir e que regule de modo geral os princípios da definição (I 2, q. 1, p. 216, esta versão apresenta um texto mais curto que o de Probl. 3, q. 6.2.1, sol., p. 153). Para Pedro a definição substancial, única que interessa à ciência da alma, não é da competência da lógica, mas sim da metafisica, assentando esta posição no livro VII da Metafisica de Aristóteles.$^{90}$ Mais uma razão para a ciência da alma se colocar sob o signo da Metafisica, mantendo a sua autonomia e dando o seu contributo para a definição de um método geral das ciências.

\section{Uma classificação das ciências e outras conclusões}

As referências dispersas sobre a organizaçăo das ciências, que fomos encontrando nos prolegómenos e no início do Commentário sobre o De anima, permitem-nos reconstituir uma arquitectónica das ciências, ressalvando desde logo que

87 Comm. I 1, q. 4, sol., p. 202-203; idem no Probl. 3, q. 6.1.5, sol., p. 146.

88 Idem, ibidem, Ad rationes, p. 203-204 e p. 146-147. A questão seguinte, e última desta lição, ocupa-se já do objecto próprio desta ciência da alma, definindo a alma como forma primeira de todos os corpos animados (I, 1, q. 5, p. 204-207 e p. 147-150).

89 Com 10 questőes (p. 214-235), as cinco primeiras também haviam sido inseridas na última parte do Problema preambular 3 (p. 150-162).

90

Comm. I 2, q. 2, p. 218, = Probl. 3, sol., p. 156 
em nenhum local se encontra a divisão das três grandes áreas do saber (especulativo, prático e sobre a linguagem) embora essa possa ser inferida do cruzamento de diversas passagens: ${ }^{91}$

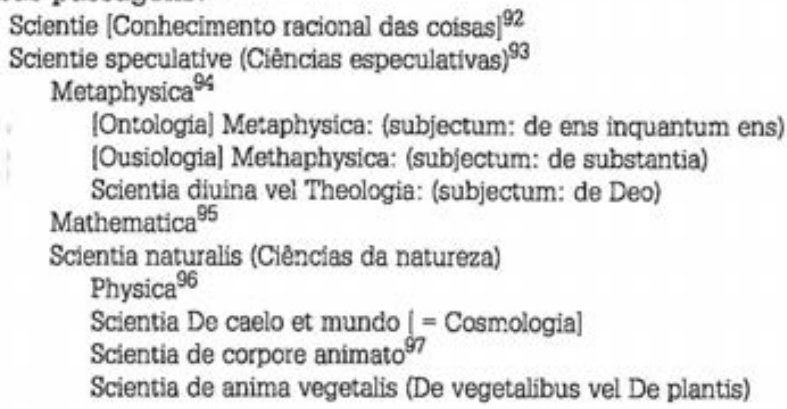

91 Se representado graficamente o esquema teria um desenvolvimento arborescente do tipo:

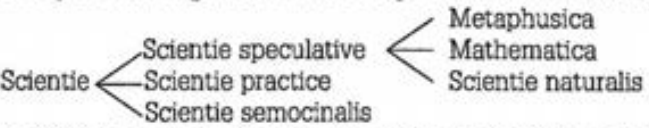

A divisão do conhecimento das coisas em "scientie speculative" sobre as coísas que não dependem ou săo anteriores ao nosso agir e em "scientie practice vel morales" sobre as coisas que resultam do nosso agir, tem origem em Aristóteles (p. ex. Metafisica VI 1, 1025b25) mas é no texto atribuida a Avicena, embora seja retomada do inicio da Metafisica de Algazel (Algazel's Metaphysics I 1, ed. Muckle, p. 1, 20-26), cfr. Comm. I 1, q. 1.5, $2^{\mathrm{a}}$ ratio ad op., p. 1-11 (= p. 138).

A tripartição das ciências especulativas segundo o "status rerum", isto é segundo a conjunção ou separação do movimento e matéria, encontra-se no Probl. 2, q. $11,1^{\circ}$ ratio, p. $75,14-21$, com remissão para Aristóteles [Meta. VI 1]. Pedro chama-lhes "scientie principales" e "partes princípales philosophiae" ao explicar que o género de abstracção origina diferenças de definição, no Probl. 2, q. 20, sol., p. 107, 1-3. A tripartiçăo com base no modo de abstracção encontra-se também em Probl. 3, q. 1, sol., p. 111, 16-17 (ver acima n. 66), que permite corrigir as lacunas de transcriçăo em I 7, q. 3, ad lam rat., p. 314, 9-26. Subentende-se que a ciência da alma é "scientia speculativa" e não uma "scientia practica vel activa" em I 1, q. 3, p. 201, 1-3. A divisåo da filosofia teorética em matemática, fisica e filosofia primeira ou teologia, em razăo dos seus objectos, tem origem em Aristóteles (Metafisica VI 1, em especial 1026a11-32), divisão que se lê também em De anima I 1, 403b9-17 em razão do modo como cada um aborda as afecçōes do corpo, segundo o modo de pertença, abstracçăo e separação. A tripartiçăo aristotélica das ciências especulativas foi desde o ínicio da Idade Média transmitida ao mundo latino por Boćcio com as designaçǒes "naturalis", "mathematica" e "theologica" (De Trinitate II, p. 30, 1. 5-21, ed. Stewart, Rand, and Tester na Loeb Cl. Library, Harvard Univ. Press, Cambridge Mss. 1990 repr.), tendo sido múltiplas vezes giosada e integrada nas classificaçð̄es das ciências dos séc. XII e XIII (ver por exemplo os esquemas apresentados em WBISHBIPL, "The Nature, Scope, and Classification..." p. 468, 471, 474; 480, DAHAN "Les ciassifications du savoir..." p. 15, 16, 18; O. WELJERS, Le maniement du savoir..., p. 189, 1934, 201). Pedro reordena a sequência boeciana.

94 Sobre o tripo objecto (subiectum) da Metafisica: I 1, q. 1, rat. 1, p. 185, 20-28 e múltiplas outras passagens (ver acima n. 40 e 75). Noutro lugar e usando outra terminologia de classificação, a Metafisica e a Fisica são ambas referidas como "ciências naturais" superiores à da alma (p. 202, 17-19), tal como no "Guia do estudante" parisiense, cfr. Cl. LAFLBUR - coll. J. CARRIER (eds.) Le "Guide de l'étudiant" d'un maitre..., ed. cit., §§ 4, 9 e 59.

A Matemática é apenas entendida como ciência da quantidade abstraída, sem consideração do movimento e da matéria (p. ex. Comm. I 1, q. q. 1.2, p. 189-191). Nunca é referida a divisão tradicional da Matemática (aritmética, geometria, astronomia e música) e duas das suas partes tradicionais (a astronomia e a música) são pontualmente referidas como ciências independentes.

97 Comm. Probl. 1, q. 13 sol., p. 81 10-25; q. 14, p. 83, 26-84, 15. 
Scientia de anima sensibilis (De animalibus)

Scientia de anima: de corpore animatum inquantum refertur ad animam et ad operationes anime; de anima secundum omnem sui differentiam (De anima)

Scientia de libris minoribus: actos do corpo animado (Libri minores: De sompno et vigilia, De morte et vita, De inspiratione et respiratione)

Medicina ${ }^{98}$

De motu animalium

Musica $^{99}$

Astronomia [ = Astrologia $]^{100}$

Scientie practice vel active vel morales (Ciências práticas ou morais) ${ }^{101}$

Scientia moralis ${ }^{102}$

Scientia de regimine civitatum

Scientie sermocinalis (Ciências da linguagem) ${ }^{103}$

Logica (subjectum: sillogismus)

Grammatica (subjectum: oratio)

Rethorica (subjectum: causa vel questio civilis, oratio rethorica)

O estudo da alma é, assim, situado num todo mais vasto, submetido, como acontece nas habituais classificações das ciências, a uma organização vertical idêntica à própria dignidade das coisas, esquema este que evita quer a exclusão de alguma forma de racionalidade, quer a sua desagregação em esferas ontológicas isoladas entre si. Nos textos analisados há um evidente esforço argumentativo, que năo evita algumas contradições e algumas formulaçöes ad hoc nem sempre consequentes, para fazer coincidir a divisão das ciências com o conjunto das leituras ao longo do curniculum da Faculdade de Artes, onde as obras de Aristóteles ou a ele atribuídas foram progressivamente ocupando todo o espaço lectivo e de debate científico. Ao esquema hierárquico aqui proposto corresponderá uma outra ordem pedagógica de leitura e estudo das obras de Aristóteles, nomeadamente no que diz respeito ao corpo animado, daí as hesitaçōes de Pedro quanto à dignidade de cada ciência (que nuns casos releva do seu status e noutros do seu objecto).

o Comentário sobre o De anima de Mestre Pedro, onde quer que ele tenha sido leccionado, testemunha a tendência universitária bem visivel no século XIII para tomar o corpus aristotélico como delimitação e autoridade máxima no campo filosófico, ${ }^{104}$ esteriotipando o conteúdo de cada obra e transformando cada uma de

98 Ver acima n. 50.

99 A Música é referida (Probl. 2, q. 7, p. 93) no contexto da comparação da ciência da alma com as ciências naturais, a propósito da voz "et sic determinatur de ipsa in Musica", o que parece indicar a referência ao título de uma obra e nunca é referida como parte da Matemática.

$: 00$ Ver acima n. 51.

${ }^{101}$ As "scientie practice vel morales" são sobre as coísas que resultam do nosso agir, ver acima n. 92; Em I 1, q. 3, p. 201, 1-3 também se encontra a designaçåo "scientia practica vel activa".

102 Note-se que Peciro parece não conhecer nem as Éticas, nem a Politica de Aristóteles, nem a Economia do pseudo-Aristóteles.

103 "Scientie vero sermocinalis ut logica sunt de signis", I 1, c. 1.6, 2um ad op., p. 198, 28-29 (idem p. 3-4). Sobre a distinção entre scientiae de rebus e scientiae de signis no In De animalibus e na obra médica Super Tegni Galeni de Pedro Hispano ver as p. 108-111 do estudo de S. NAGEL, "Scienze de rebus et discipline de vocibus..." p. 108-111 e o estudo "Artes, scientiae e medicina nel commento ai De animalibus di Pietro Ispano", ambos citados acima.

$104 \mathrm{Ctr}$. G. DAHAN, "Les classifications du savoir..." p. 18; Ch. LOHR, "The Medieval Interpretation...", art. cit. e "The New Aristotle and 'science'...", art. cit. 
per si (juntamente com outras a que o seu nome era associado) em ciência autónoma. A restrição da ciência ao corpus aristotélico e peripatético é tal que quase repentinamente se abandona a estruturação do saber sobre as artes liberais (trivium e quadrivium), ${ }^{105}$ diluindo e distribuindo algumas das suas disciplinas no interior de uma nova classificação muito mais ampla. A autoridade atribuída ao corpus aristotélico é denunciado pelas referências ao conteúdo de cada uma das suas obras como encerrando a "scientia" ou "conhecimento certo" sobre o respectivo objecto e realçado pela ambigua citação das ciências pelo título das obras de Aristóteles. Também em matérias metodológicas, sobre as quais Aristóteles apenas escreveu tratados lógicos que a Mestre Pedro parecem insuficientes para se ocuparem da substância, procura construir uma teoria do universal, da indução abstractiva e da teoria da definição substancial com base nos Segundos Analíticos II, 19 e no livro VII (Z) da Metafisica. É por esta deliberada aproximação à metafisica aristotélica, paralela à desvalorização da biologia, que a ciência da alma reivindica a sua superioridade como ciência gnosiológica fundamental.

A argumentação e a natureza dos problemas preambulares aproximam a abertura do Comentário de Pedro da literatura de manuais e introduçōes à filosofia que proliferam em Paris em meados do século XIII e certamente também em outras universidades. Verdadeiro discurso de investidura da dignidade da função magistral, oferece-nos de modo disseminado uma classificação das ciências cujos fundamentos são discutidos com mais pormenor que na maioria daqueles textos de introdução à filosofia. Certamente que Pedro conhecia os guias introdutórios académicos, mas a forma de discurso dos mestres, nem sempre sistemática, muito repetitiva ou contraditória por necessidade de discussão, como acontece aqui, poderia incitar à organização de um texto mais claro e coerente. Estas questões preambulares e muitos outros comentários sobre Aristóteles que comportam divisões das ciências, poderão sugerir que as "Introduçōes à filosofia" resultam de cursos como este a que alguém, nalguns casos o próprio Mestre, deu uma organização, consentânea com as práticas de avaliação na universidade. Os comentários de obras de Aristóteles pelos mestres de Artes, utilizando materiais de múltiplas proveniências, em especial dos filósofos árabes e arabizantes, mais do que dependerem dos manuais universitários de elogio e divisão da filosofia, deverão estar na sua origem ou pelo menos fornecem-lhes os elementos que explicam as diferentes abordagens da classificação das ciências, cirurgicamente moldadas a cada obra que estava a ser comentada.

Quanto à natureza filosófica da ciência da alma fica bem sublinhada quer pela sua inserção no campo das ciências naturais, quer pelas relações que estabelece com estas e com as ciências que lhe são superiores (Metafisica e de certo modo também a Física) e inferiores (sobretudo Parva naturalia), ou propedêuticas (lógica), a relação com as ciências morais embora aflorada merece pouco interesse. A

${ }^{105}$ A situaçăo é bem diversa nas obras médicas atribuidas a Pedro Hispano, sobretudo no In De animalibus, onde perdura a divisāo do saber em artes liberais, cfr. S. NAGEL, "Artes, scientiae e medicina...", p. 56-58. 
comparação entre os objectos e os modos de demonstraçâo da ciência da alma e das outras ciências, permitiu concluir que à ciência da alma é superior a todas as outras por razōes que se prendem com a própria natureza do conhecimento, com o seu objecto e actor que é o homem, a mais digna e fim último das criaturas e sobretudo em razão da coincidência entre o cognoscente e o conhecido no intelecto humano.

Em suma, a ciência da alma, que comporta simultaneamente uma psicologia filosófica, uma gnosiologia ou noética e uma ontologia das formas abstraídas, é teorizada no Comentário de Pedro como coroação e de certo modo como coração epistemológico dos estudos filosóficos, porque é uma ciência do homem: "homo nobilius est subiectum et sua scientia nobilior que est scientia de anima". 106

${ }^{106}$ P. $194,26-28$, ver acima n. 81. 